\title{
Hermano moro: masonería y colonialismo en el Protectorado español de Marruecos (1931-1936)
}

\author{
Moorish Brother: Freemasonry and Colonialism in Spanish \\ Protectorate of Morocco (1931-1936)
}

\author{
Valeria Aguiar Bobet \\ Universidad Jaume I de Castellón, España \\ vaguiar@uji.es
}

Recepción: 19 de octubre de 2017/Aceptación: 25 de noviembre de 2017

doi: https://doi.org/10.15517/rehmlac.v9i2.31167

Palabras clave

Masonería; Protectorado español de Marruecos; imaginario; colonialismo; indígenas; musulmanes.

Keywords

Freemasonry; Spanish Protectorate of Morocco; Imaginary; Colonialism; natives; Muslims.

Resumen

Para los masones españoles, el "hermano moro", título que enmarca el artículo, no es solo un hermano masón más, es un hermano excepcional, construido desde el canon colonial y el pasado común compartido en una época medieval distorsionada, un hermano histórico pero infantilizado, necesario para legitimar la actuación masónica en el Norte de África. En este sentido, el texto aborda la construcción de la imagen del "otro musulmán" mediante el análisis del discurso colonial de la masonería hispana implantada en el protectorado marroquí desde finales del siglo XIX. Con tal fin, se analizará la construcción del "indígena" y la propia evolución de dicha construcción desde los discursos y las prácticas masónicas. Sin olvidar, por último, las consecuencias y particularidades que los límites discursivos de ambas variables (el constructo y su recepción) supondrán para la consecución del ideal masónico colonial proyectado por las logias norteafricanas.

\begin{abstract}
For the Spanish Masons, the "Muslim brother", title of this article, is not a Mason more, he is an exceptional brother constructed from the colonial canon and the common shared past in a medieval distorted epoch, a historical but childish brother, necessary to legitimize the Masonic performance in the North of Africa. In this respect, the text addresses the construction of the image of the "other Muslim"by analyzing of the colonial discourse of the Hispanic Freemasonry implanted in the Moroccan protectorate since the late 19th century. However, last but not least, the consequences and particularities that the discursive limits of both variables (the construct and his reception) will suppose for the attainment of the ideal colonial Masonic projected by the North African lodges.
\end{abstract}


De todas las actitudes, motivaciones y formas de percepción presentes en la sociedad española "como sedimento de una larga experiencia histórica", la más intensamente socializada en la conciencia de los españoles sigue siendo el viejo antagonismo hispano-moro.

José María Jover ${ }^{1}$

\section{Introducción}

Los fondos documentales coloniales españoles se han comprendido, en los últimos años, como un lugar de definición de posibilidades para la producción de conocimiento y formación de identidades ${ }^{2}$. El Archivo General de la Administración, el Archivo Histórico Nacional, el Archivo de Indias, entre otros, no solo se configuran, de este modo, como entidades que recogen distintos discursos producto del bagaje histórico al que pertenecen, sino que sus fondos se convierten per se en productores y formadores de esos mismos discursos que, al fin y al cabo, conformaron el conocimiento y las identidades de sus respectivos contextos. En este mismo sentido, los fondos relativos a la historia de la masonería colonial española, ubicados en el Centro Documental Histórico de Salamanca, asumirían el mismo rol. Y la masonería, dado su carácter específico como institución ajena a la administración civil, con sus propios estatutos, códigos y dinámica interna, que hacen que se sitúe en la tipología de sociedades cerradas o semi-cerradas ${ }^{3}$, sería la responsable de la construcción y re-construcción de la narrativa desarrollada en su documentación; narrativa que iría acorde con sus diferentes dinámicas contextuales, a veces parejas y a veces diferenciadas del canon colonial genérico producido por los otros fondos coloniales nacionales.

Si bien en otra ocasión nos aproximamos a la percepción y recepción de dicha narrativa en el Norte de África por parte de las diferentes culturas que integran este territorio (cristianos, musulmanes y judíos) ${ }^{4}$, en este texto, pretendemos profundizar, específicamente, en la percepción de la otredad musulmana que subyace detrás de este discurso. Nos centraremos, sobre todo, en la objetivación del musulmán desde el "ideal

\footnotetext{
1 José María Jover, "La percepción española de los conflictos europeos: notas históricas para su entendimiento", Revista de Occidente 57 (1986): 13-42.

${ }^{2}$ Benita Sampedro Vizcaya, "Rethinking the Archive and de Colonial Livrary: Equatorial Guinea", Journal of the Spanish Cultural Studies 9, no. 3 (2008): 342.

${ }^{3}$ Véase la obra de Céline Bryon-Portet, Sociologie des sociétés fermées. Imaginaire symbolique et sacralité en milieu clos (Montpellier: PULM, 2013).

${ }^{4}$ Valeria Aguiar Bobet, "La cultura de la tolerancia en el Marruecos de la II República: el VIII Centenario de Maimónides", en La masonería hispano-lusa y americana, De los Absolutismos a las Democracias (18152015), coords. Miguel Delgado e Yván Pozuelo (Zaragoza: CEHME, 2017), Vol. II, 493-506.
} 
masónico colonial ${ }^{5 "}$ y el imaginario cultural del que parten las logias españolas en Marruecos, configurando diferentes identidades ex profeso: el ser masón musulmán, el ser indígena, el ser protegido o el ser protector. Y es que, al fin y al cabo, el "hermano moro", título que enmarca el artículo, no fue solo un hermano masón más, fue siempre un hermano excepcional construido desde el canon colonial español y el pasado común compartido en una época medieval distorsionada. Fue, sobretodo, un hermano histórico inventado o reconstruido entre su infantilidad, incivilización y su ilustre pasado andalusí, caracteres necesarios para legitimar su misión civilizadora y cosmopolitizadora ${ }^{6}$ en el Norte de África.

En definitiva, las líneas que siguen abordan la percepción estética y simbólica del “otro musulmán", mediante el análisis del discurso colonial de la masonería hispana implantada en el protectorado marroquí desde finales del siglo XIX. Con tal fin, se analizará la construcción del "indígena" y la propia evolución de dicha construcción en los discursos y prácticas masónicas. En primer lugar, desde la concepción y percepción de la imagen general del "moro" construida en la sociedad española a través de su trayectoria histórica y, en segundo lugar, al respecto de la iniciación o exclusión de musulmanes en la historia de la masonería europea, sobre todo, en la masonería colonial francesa. Junto a ello, en un sentido bidireccional, el texto abordará la asunción y asimilación - o no- de esta construcción narrativa por parte del "otro musulmán masón", así como los problemas derivados de dicha conceptualización y objetivación. Sin olvidar, por último, las consecuencias y particularidades que los límites discursivos de ambas variables (el constructo y su recepción) supondrán para la consecución del ideal masónico colonial proyectado por las logias norteafricanas. Solo así podremos deducir en qué medida el discurso masónico construido a través de los textos y prácticas preservados en el Centro Documental de la Memoria Histórica produjeron conocimiento y formaron identidades, con todo lo que esto implica desde un punto de vista sociocultural, en los casi cincuenta años ${ }^{7}$ de ocupación masónica del protectorado magrebí.

Utilizaremos para ello, la concepción foucaultiana de "construcción" de los discursos. Es decir, su condición dinámica, modificable y cambiante, que se fundamenta, se fragiliza y está atravesada por voluntades diversas, por diferentes instancias del deseo, por

\footnotetext{
5 Aguiar Bobet, "En busca de la colonia perfecta: ideales masónicos en Cuba y Marruecos" (ponencia presentada en V Simposio Internacional de la Masonería Latinoamericana y Caribeña, La Habana, 26-30 de junio de 2017).

${ }^{6}$ Valeria Aguiar Bobet, "En busca de la colonia perfecta", 2017.

${ }^{7}$ En Melilla, los primeros talleres pudieron haber sido las logias Amor y Excelsior en 1874. Vicente Moga Romero, Al oriente de áfrica. Masonería, Guerra Civil y represión en Melilla (1894-1936) (Melilla: UNEDCentro Asociado de Melilla, 2002), vol. I, 88. En Ceuta, las logias Africana no. 112 en 1876, Hijos de la Africana no. 191 y África no. 50, constituidas en torno a 1880, las tres del Gran Oriente de España. Centro Documental de la Memoria Histórica (CDMH), Sección Especial (SE) Masonería A, Legajo (L). 605 Expediente (E). 2. El final de la masonería española en Marruecos corresponde con el inicio de la guerra civil en 1936, aunque la desestabilización de la orden se iniciaría desde 1934.
} 
la verdad y la voluntad de verdad, con sus propios procedimientos internos, sus principios de clasificación, ordenamiento, distribución, desfases, rituales y, por tanto, con sus propias exclusiones y sus formas de adecuación social. El discurso con una dinámica interna, como lo señalaba Michel Foucault en su clásica conferencia de ingreso al Collège de France en $1970^{8}$.

\section{Bárbaros, exóticos, niños y hermanos: la imagen del "moro" en España}

Hace poco más de unas décadas, los estudios de Edward Said ${ }^{9}$ y Valentin Mudimbe $^{10}$ han puesto de relieve que, tanto "Oriente" como "África", devienen como producto discursivo de Occidente. Bajos tales premisas, las potencias coloniales europeas organizaron, inventaron y recrearon la memoria colectiva eurocéntrica en una larga trayectoria desde el siglo XV hasta hoy, que en nada se relacionan con las memorias y creaciones desarrolladas en los propios territorios que constituyeron ambos términos. La modernidad europea, con su espíritu iluminista y su concepción lineal de la historia heredada de la cultura semita, instituyó las ideas de progreso y civilización como centrales en la justificación de la obra, o más bien, "misión” colonial, asociada a la creencia en la desigualdad de los humanos mediante el concepto de raza. Raza, entonces, como categoría discursiva, establecería marcas de diferenciación social mediante oposiciones binarias que generarían una relación de poder y desigualdad entre los polos blanco-superior-civilizado y negro/indígena-inferior-salvaje, fundando así la inmutabilidad del statu quo colonial. ${ }^{11}$ En este sistema relacional, el dominador crea las imágenes de salvaje, primitivo, bárbaro como forma de identificación del dominado, justificando, de tal modo, la portación de civilización. El representando no se considera como un interlocutor, como un agente, sino en una perspectiva pasiva, silenciosa, controlada y dispuesta a ser cristalizada en imágenes estereotipadas como bárbaras ${ }^{12}$. Y en este proceso constructivo y de producción, la ambivalencia, la repetición y el estereotipo, se convierten en sus características inherentes, engendrando continuas imágenes genéricas de infantilidad y barbarismo de los sujetos colonizados por partes de agentes diversos al servicio de la obra colonial (la administración civil, la milicia, la masonería, etcétera). Sujeto y agente representan así, las relaciones de

\footnotetext{
${ }^{8}$ Ana Pizarro, "Colonialidad: observaciones sobre la construcción de discursos", Taller de Letras 53 (2013): 83-86.

${ }^{9}$ Edward Said, Orientalismo, trad. María Luisa Fuentes (Madrid: Quilba,1990).

${ }^{10}$ Valentin-Yves Mudimbe, The invention of Africa (Indianápolis: Indiana University Press, 1998).

${ }^{11}$ Ana Lucia Sá, "La construcción de la imagen del indígena en las poblaciones españolas del Golfo de Guinea (1904-1912)", en Tras las huellas del colonialismo español, coord. Yolanda Aixelá Cabré et al. (Madrid: CSIC, 2015), 92-93.

${ }^{12}$ Said, Orientalismo.
} 
superioridad-inferioridad. El primero se somete al poder ejercido por el segundo, mientras este se autodefine en un nivel superior.

En este sentido, la categoría raza es esencial en la construcción de la diferencia, así como otros tópicos como la sexualidad, el género, la religión, lo que permite la variación y la contextualización de los discursos que conformaron la identidad del sujeto colonizado por la misión civilizadora de España. Esta identidad se resumió, genéricamente, en el concepto central de indígena explicada en términos de homo infantilis, un "noevolucionado". Si bien este concepto surge sobre todo a raíz de las nuevas incorporaciones africanas, como Golfo de Guinea y Fernando Poo ${ }^{13}$, tal retrato se impondrá también en los discursos asociados a los marroquíes musulmanes como nativos de esa región. Sin embargo, en esta ocasión, el "indígena" de Marruecos difería sustancialmente de los otros nativos. Los musulmanes marroquíes, coloquialmente denominados "moros"14, portaban una relación histórica común con los españoles. No es de extrañar que hasta la I Guerra Mundial "África" significase, sobre todo, "Marruecos"15. Esto hace que la construcción del "indígena moro" se haya conformado de forma significativamente diferente, aunque sea también producto y consecuencia del canon colonial europeo y español que hemos visto. La razón es obvia, los largos años de ausencia física del territorio español por parte de los "moros", fueron conformados y definidos no solo por el recuerdo de los ocho siglos de la así llamada Reconquista, las continuas razias, piratería y saqueos por las costas mediterráneas, sino también por la política expansionista española en África del Norte, especialmente del siglo XV al XVII, y del XIX al XX.

Eloy Martín Corrales, en su libro La imagen del magrebi en España ${ }^{16}$, realiza un recorrido histórico a través de las diferentes percepciones iconográficas en torno al musulmán marroquí por parte de los españoles. Estas representaciones pictóricas, que poco difieren de las originadas en los discursos escritos, llevan al autor a establecer que, en líneas generales, la imagen percibida ha sido tan negativa como discontinua, tan estereotipada como ambivalente ${ }^{17}$. Es más, esta cuasi permanente negatividad no tuvo la misma intensidad ni siempre fue uniforme. Al contrario, experimentó cambios

\footnotetext{
${ }^{13}$ Se inicia en 1904 por el Real Decreto del 11 de junio de 1904 y se mantiene hasta más o menos 1928. Raúl Sánchez Molina, "Homo infantilis: asimilación y segregación en la política colonial española en Guinea Ecuatorial”, Revista de Dialectología y Tradiciones Populares 57, no. 2 (2002): 109.

${ }^{14}$ A pesar de las connotaciones peyorativas que este término pueda suponer en la actualidad, "moro" proviene de latín maurus "mauritano", y este del griego maṽpos maûros que significa propiamente 'oscuro', por alusión al color de su piel. De dicho término, además, proviene la denominación de la provincia romana Mauritania por lo que en su origen no tendría una indicación especialmente negativa. Diccionario de la Real Academia Española, http://dle.rae.es/?id=PqZDbAp

${ }^{15}$ Gustau Nerín, La última selva de España. Antropófagos, misioneros y guardias civiles (Madrid: Catarata, 2010), 37.

${ }^{16}$ Véase Eloy Martín Corrales, La imagen del magrebi en España. Una perspectiva histórica siglos XVI-XX (Barcelona: Bellaterra, 2002).

${ }^{17}$ Martín Corrales, La imagen del magrebí, 23.
} 
significativos a lo largo de los siglos provocados por una doble evolución en las relaciones hispano-musulmanas:

La decadencia moral y cívica en épocas de tiranía y dictadura favoreció en líneas generales una percepción de los marroquíes o muy negativa o muy impregnada de paternalismo. Por el contrario, el resurgimiento de valores como la tolerancia y la solidaridad en periodos democráticos propició que se suavizaran los tonos sombríos con que eran contemplados los marroquíes y que algunos sectores de la sociedad expresaran la necesidad de establecer unas relaciones de igual a igual con el vecino $\operatorname{sur}^{18}$.

Y esto se explica, entre otros factores, por la íntima relación histórica entre españoles y marroquíes a través de negaciones y rechazos del "otro". La construcción se realizaba -y se realiza- por lo que no sé es, es decir, el no ser cristiano y el no ser civilizado. Por tanto, los elementos que configurarían la negación, en este caso, serían la religión y la civilización. Habiendo sido construido sobre esa base y habiendo sufrido un proceso de demonización, el "otro" se vuelve un objeto emocionalmente cargado que puede ser "manipulado, preservado y convocado a voluntad" por los miembros del grupo, poseyendo la capacidad de desencadenar emociones poderosas y reacciones de tipo "mecánico" "19.

De este modo, la "otredad" musulmana está arraigada, según dicho autor, en conflictos y choques de intereses a lo largo de la historia entre la España cristiana y miembros específicos del mundo árabe-musulmán (la dinastía Nazarí y los independentistas marroquíes, por ejemplo), generando niveles cambiantes de islamofobia/maurofobia, a pesar, incluso, de que estas imágenes y estereotipos negativos no hayan sido siempre los dominantes. El otro musulmán se muestra así relegado a una raza esencialmente inferior. Y este rol ha sido fundamental, no sólo al galvanizar una conciencia étnica-cristiana, sino también al legitimar la expansión y ocupación colonial de España en el Magreb por los diferentes agentes civilizatorios, entre los que se encuentra, por supuesto, la masonería. ${ }^{20}$ Todo ello sustentado sobre un principio dialéctico que confrontaba a la religión musulmana y el progreso occidental.

\footnotetext{
${ }^{18}$ Martín Corrales, La imagen del magrebí, 23.

${ }^{19}$ Henri Zukier, "Transformation of Hatred: Anti-Semitism as Struggles for Group Identity", en Demonizing the Other: Antisemitism, Racism and Xenophobia, coord. Robert. S. Wistrich (Londres: Routledge, 2003), 118-130.

${ }^{20}$ Raanan Rein y Martina Weisz, "Fantasmas del pasado, desafíos del presente: nuevos y viejos «otros»", en El otro en la España Contemporánea, Prácticas, discursos y representaciones, coords. Silvina Schamma Gesser y Raanan Rein (Sevilla: Fundación Tres Culturas, 2011), 181-182.
} 
No obstante, Susan Martín-Martínez precisa en su ensayo Desorientaciones ${ }^{21}$ que la trayectoria española frente a la construcción del "otro musulmán" se apartó en varias ocasiones de la europea en su expansión imperialista, precedida y secundada por el triunfo del orientalismo del que, particularmente, no participaría España. Es más, considera, bajo el concepto de lo performativo ${ }^{22}$, dos premisas importantes en la identificación nacional española, que afectan directamente a su identificación del otro musulmán. Primero, que España resulta a la par orientalizadora y orientalizada ${ }^{23}$ y, segundo, que, a través de sus dos oleadas de identificación nacional, el musulmán es percibido de formas diversas, plurales, en función y en relación del sector social, el individuo o el periodo histórico que lo defina, y no tanto por la contraposición entre islamofobia/maurofobia e islamofilia/maurofilia planteada por Martín Corrales ${ }^{24}$.

Siguiendo a esta autora, el debut de la primera oleada de identificación nacional, que surge como consecuencia de los acontecimientos sucedidos en torno a 1492 (final de la Reconquista, expulsión de los judíos, el descubrimiento de América), se basaría en la exclusión selectiva de los "otros" religiosos. Pero que, dada la ausencia de claros indicadores externos de diferencia en este discurso pro-cristiano (por las conversiones masivas al cristianismo de judíos y musulmanes), se plantearía dicha incompatibilidad a partir de elementos racializantes más potentes, es decir, la sangre y otros rasgos biológicos - muchas veces inventados- La preocupación por la diferencia cultural se transformaría entonces en miedo a la diferencia biológica, y su consecuencia más inmediata supuso como resultado la animalización de los moriscos. A partir de este momento, se empezaron a considerar como portadores de enfermedades y su presencia se juzgó, en última instancia, como una amenaza, ya no solo a la fe católica sino a la sangre española.

Sin embargo, después de esta primera oleada basada en una uniforme entidad católica de etnia y razas puras, desde finales del siglo XVIII y principios del XIX, se iniciaría un constructo disímil: se comenzarían a excavar los rastros de densas capas que dejaron tras de sí los nueve siglos de coexistencia entre cristianos, musulmanes y judíos. Proceso por el cual comenzaría a asociarse la herencia africana española y sus aspiraciones coloniales en África. El exotismo y otras representaciones de esa índole plagaron las diferentes narrativas y producciones artísticas. No solo se había descubierto el rico y culto pasado andalusí español, convirtiéndose en el tópico perfecto para participar en la

\footnotetext{
${ }^{21}$ Véase Susan Martín-Márquez, Desorientaciones. El colonialismo español en África y la performance de la identidad (Barcelona: Ediciones Bellaterra, 2011).

${ }^{22}$ En el concepto performativo, las categorías sociales son irreductibles, es decir, cada una existe en función de las otras, aunque de forma contradictoria e irregular.

${ }^{23}$ Continúa diciendo la atora al respecto de la obra de E. Said que "para los españoles, este posicionamiento en ambos "lados" del orientalismo -como el "yo" y el "otro" simultáneos- puede llevar a un profundo sentido de “desorientación"”. Susan Martín-Márquez, Desorientaciones, 22.

${ }^{24}$ Eloy Martín Corrales, "Maurofobia/islamofobia y maurofilia/islamofilia en la España del siglo XXI", CIDOB de Afers Internacionals 66-67 (2004): 39-51.
} 
Ilustración europea (sobre todo francesa), sino que este hecho había planteado la cuestión clave de hasta qué punto los "moros" y "moriscos" serían parte del "nosotros en el pasado" que constituía la historia nacional. Por tanto, al tiempo que numerosas naciones-estado modernas se formaban por primera vez, el país se embarcaba en la segunda oleada de construcción nacional con importantes sectores de la población promocionando una visión iconoclasta del pasado colonial. Y esto a pesar de que los partidarios de la tradición luchaban por reforzar su entendimiento de la historia más hegemónica. Además, coincidiendo con la pérdida de las colonias en las Américas, esta era de "reconstrucción" nacional también estaría acompañada del gesto compensador de la segunda oleada de colonización, cuando los "africanistas" españoles comenzaron a abogar por la búsqueda de un nuevo futuro imperial en el continente africano.

Hacia las últimas décadas del siglo XIX, este cuestionamiento de la opinión general sobre la historia española, había comenzado a filtrarse en una variedad de esferas públicas, modulando la codificación de espacios y objetos culturales concretos y, además, redefiniendo de una forma más amable a los antiguos bárbaros marroquíes. No obstante, dicha perspectiva tendría que asimilarse de algún modo, o rechazarse, por lo general, con suficiente vehemencia para traicionar una ansiedad subyacente ${ }^{25}$. En este sentido, los españoles no eran ajenos al escarnio racista y los menosprecios orientalistas que habían emergido durante la era romántica al respecto de la Leyenda Negra, que impedía, entre otras cosas, que España escapara a la asociación con la otredad incivilizada. Es más, la obsesión de los españoles con la pureza de sangre era prueba obvia de su impureza, un acto, a los ojos de las naciones europeas, en sí mismo, barbárico. La consecuencia de ello fue, por un lado, el reforzamiento de la "hermandad" y del "espíritu de raza" con todas las excolonias americanas y, por otro, una orientalización más exacerbada de España por los europeos, resumida en el famoso dicho: "África comienza en los Pirineos". El discurso, de sobra conocido de la "hispanidad", buscaba subliminar la cuestión de raza, justificándose por medio de la religión y de la lengua, aunque sin lograr nunca desplazar las interpretaciones biológicas del discurso cultural. En cuanto a los vecinos marroquíes, el avance de las potencias europeas por África abría un nuevo camino para la regeneración española en su intento de colonización, a pesar de que esto suponía una carrera competitiva en clara desventaja. España debía rivalizar con las potencias más influentes y hegemónicas de la geopolítica imperialista: Inglaterra, Francia y Alemania. Apelaban para ello a su afinidad geográfica, histórica, cultural e incluso racial con África y los africanos a fin de demostrar que estaba mucho más capacitada que estas naciones para dicha labor. Por tanto, del mismo modo que los académicos españoles antes y durante la época de la Ilustración, el país buscaría ahora legitimar su participación en el proyecto colonial enfatizando su relación excepcional con África mediante referencias a su legado andalusí.

\footnotetext{
${ }^{25}$ Martín-Márquez, Desorientaciones, 49.
} 
Sin embargo, dadas las políticas raciales de la época, las intervenciones militares surgidas por conflictos diplomáticos, entre otros factores ${ }^{26}$, la imagen de los marroquíes volvía a surtirse de los peores estereotipos de la barbarie, indolencia y lascivia, para instar a España a emprender la "santa misión" de civilizar al país vecino. La nación tenía el deber moral de restaurar esta población, población que una vez había contribuido tanto a la gloria nacional. Incluso Joaquín Costa argüiría, explícitamente, que los españoles y marroquíes estaban destinados a vivir juntos como hermanos, ya que, de hecho, compartían una hermandad de sangre", aunque más adelante negase la preparación de España ante dicho reto $^{27}$. Los resultados del discurso no tardarían en aparecer: en 1906, se firma el Tratado de Algeciras por parte de las potencias europeas que autorizaba la colonización de Marruecos a Francia y España ${ }^{28}$, estableciéndose, de forma oficial y definitiva el protectorado francoespañol en 1912, con toda la potencia conceptual que dicho término-protectoradoimplicaba.

A partir de este momento, la trayectoria multiforme del discurso de la identidad española y su construcción del otro musulmán, permitió que las representaciones establecidas oscilaran entre todas las variables vinculantes-bárbaro, salvaje, exótico, incivilizado, infantil, hermano-, pero siempre bajo dependencia de su contexto sociopolítico y del grupo que la definiese. De este modo, después los primeros años de la instauración del protectorado, mientras desde la oficialidad se establecía una imagen turística y beneficiosa del territorio marroquí y los marroquíes para incentivar su ocupación por españoles, las guerras del Rif(1921-1927) y la pacificación general a la que se tuvo que someter la zona española, potenciarían de nuevo los estereotipos más negativos de su representación. Hasta tal punto que muchos sectores de la sociedad española consideraban que debía abandonarse África ${ }^{29}$. Del mismo modo, en otros periodos más pacíficos como la

\footnotetext{
${ }^{26}$ Un agente consular español fue asesinado en suelo marroquí en 1844; en 1859 miembros de tribus cercanas a Ceuta destrozaron una señal de roca en la frontera con las armas de Castilla y sabotearon la construcción de un nuevo puesto de guardia español. Las escaramuzas continuaron hasta la Guerra de Tetuán que finalizaría en 1860 .

27 Citado en Martín-Márquez, Desorientaciones, 69. No obstante el discurso de Costa, tildado de "camaleónico" por la autora, se contradice en su reducto final al reconsiderar una completa europeización de la nación deplorando así la "africanización de España". Todo ello a consecuencia del Desastre del 98 y lo que supuso para la moral nacional.

${ }^{28}$ Los motivos geopolíticos de esta decisión se discutieron en la Conferencia de Algeciras, celebrada ese mismo año, y tenían la finalidad de solucionar los conflictos en torno a los intereses de Alemania, Francia e Inglaterra por el control del Imperio marroquí. El discurso colonial español no tuvo más peso que el de justificar las pretensiones inglesas y limitar la hegemonía total de Francia en este territorio. Feliciano PáezCamino Arias, "El Magreb en las relaciones hispano-francesas", Stud. His., Ha . contemporánea 13-14 (1995): 199-213.

${ }^{29}$ Existen diversos testimonios, tanto relativos a personajes políticos como no, que demuestran que hubo cierto descontento generalizado con la ocupación española de Marruecos, pero que, entre otras cosas, España estaba obligada a asumir su rol en el juego geopolítico para evitar rivalidades entre las potencias europeas. F. Páez-Camino Arias, “El Magreb en las relaciones hispano-francesas”, 199-213.
} 
Segunda República, a la par que se intensificaba una imagen más amable, aunque "infantilizada", de los norteafricanos, la participación de estos últimos en las revueltas de octubre de 1934 y durante la guerra civil, derivaría en la identificación del "moro salvaje y bárbaro" por parte de los sectores más izquierdistas ${ }^{30}$. Lejos de la uniformidad, como vemos, estos constructos siempre resultaban entremezclados y solo en algunos periodos primaba uno u otro.

Con todo, al comienzo de la guerra civil española, la construcción discursiva, de forma sui géneris, bifurcaría en dos únicos frentes, desafiando así la trayectoria multiforme adoptada hasta el momento. Por un lado, la identificación negativa por parte de "la izquierda" y, por otro, la "retórica de la hermandad" y la "comunidad de sangre"31 defendida por el sector africanista y fomentada por el franquismo. La resignificación del pasado por parte de este último fue central: el periodo andalusí era ahora representado para reconstruir un mundo común en el presente y la "tradicional amistad con el pueblo árabe" sería el eje de su nueva narrativa.

Lo curioso del caso es que, esta misma resignificación, que implicaba un mundo común en el presente, y no tanto una relación de protección propia del canon colonial, había sido planteada con anterioridad por las logias españolas situadas en Marruecos. El discurso hegemónico de la república y los regímenes anteriores a esta, nunca plantearon unas condiciones reales de vivencia común e intercultural. De hecho, si los tres grupos que habitaban en Marruecos durante su colonización (cristianos, judíos y musulmanes) compartieron los mismos espacios ${ }^{32}$ y la heterogeneidad la representaba el binomio civil/militar y no tanto la multiculturalidad ${ }^{33}$, se debió más a un desinterés y una indiferencia por parte de las autoridades que administraban el protectorado, que a un discurso político intercultural real. La similitud entre la concepción franquista y la masónica, se diluía, no obstante, en que la masonería norteafricana no incluyó en su narrativa la esencialidad religiosa (católica e islámica) por parte, al menos, de los españoles, como veremos más adelante. De todos modos, Cristiane Stallaert ${ }^{34}$, señala que la identificación étnica de los españoles con el catolicismo, no solo fue una creencia fundamental de los franquistas durante la guerra, sino que estaba también difundida entre los “rojos" españoles (socialistas, comunistas y anarquistas). Más aún, algunos (al menos) de estos revolucionarios, interpretaban su identidad cristiana como la negación del

\footnotetext{
${ }^{30}$ Véase, $M^{\mathrm{a}}$ Rosa de Madariaga, Los moros que tajo Franco (Madrid: Alianza, 2015).

31 J. Luis Mateo Dieste, "Una hermandad en tensión. Ideología colonial, barreras e intersecciones hispanomarroquíes en el Protectorado", http://bibliotecadigital.aecid.es/bibliodig/i18n/catalogo imagenes/grupo.cmd?path=1007133.

${ }^{32}$ Mimoun Aziza, "La sociedad marroquí bajo el Protectorado español (1912-1956)", en El Protectorado español en Marruecos: la historia trascendida, Vertiente jurídica, socioeconómico-demográfica y científicoeducativa, dir. Manuel Aragón Reyes (Bilbao: Iberdrola, 2013), 138.

${ }^{33}$ Mateo Dieste, "Una hermandad en tensión", 96.

${ }^{34}$ Christiane Stallaert, Etnogénesis y etnicidad en España (Barcelona: Proyecto A. Ed., 1995), 48-49 y 52-53.
} 
moro/judío, a pesar de las políticas pluralistas de la Segunda República. Y esto supondría al final, junto con los otros factores mencionados, una interpretación negativa de la otredad musulmana por parte de la izquierda política española y otra más positiva y reconciliadora por parte del fascismo, inversamente proporcional a lo que sucedía, a priori, dentro de las logias norteafricanas, más similar a la concepción que hereda el nacional-catolicismo franquista del discurso africanista liberal del siglo XIX. Y esto, teniendo en cuenta que la masonería española se identificaba, especialmente, con la II República.

Sea como fuere, la complejidad histórica y narrativa de la construcción del otro parece más una desorientación, tal y como plantea Susan Martínez. En este sentido, la contribución al discurso colonial por parte de la masonería española podría resultar mucho más esclarecedora, estática y favorable en relación con la definición construida del "otro musulmán" por el resto de agentes civilizadores, aunque partan de un mismo punto. No obstante, antes de abordar su propia particularidad y performatividad, debemos atender al propio significado del otro en la masonería en general y cómo este se erige, de forma específica, en las logias francesas. Es decir, su inclusión o exclusión de los talleres a lo largo de su historia especulativa, puesto que, al fin y al cabo, las logias norteafricanas estaban imbuidas del mismo espíritu colonizador y universalista de sus vecinas francesas.

\section{Imaginarios masónicos: la inclusión y exclusión del otro musulmán}

La masonería, desde sus propias bases conceptuales e ideológicas, ha tenido, a lo largo de su historia, una perspectiva distinta del otro, al menos distinta a las oficializadas en las sociedades e instituciones civiles europeas, su lugar de nacimiento. Es más, desde sus orígenes, se definió como una institución abierta, estableciendo, en su carta fundadora, las Constituciones de 1723, un denominador común: el acceso de todos los individuos-sin importar su religión - a la fraternidad. La primera Obligación, Concerniente a Dios y la Religión, prohibía la entrada al "ateo estúpido" y a los "libertinos religiosos", de forma que solo pudiesen acceder los hombres de bien, leales, honorables e íntegros que sostuviesen creencias religiosas que ayudarían a distinguirlos. No obstante, estas reglas distintivas

pretendían mantener la esfera masónica al refugio de las querellas religiosas en relación a la Europa católica y la Europa "reformada", y no tanto a una pluralidad religiosa no cristiana. Sin olvidar, de todos modos, que el voto de la comunidad podía condicionar la recepción del otro religioso.

Por otro lado, pese a ser una institución cerrada en algunas de sus formas, partía de un principio universalista, subyacente en la modernidad en la que nace, por medio del cual pretendía abrirse y expandirse a todas las fronteras, tanto geográficas como culturales, para 
extenderse, en último lugar, a la humanidad entera ${ }^{35}$. Pierre-Yves Beaurepaire resume bien esta dialéctica entre el deseo de la individualización y el reconocimiento de la alteridad: "escuela de la diferencia, la francmasonería es sinónimo de búsqueda de la identidad; enseña a descubrirse, a construirse individualmente, pero desde un proceso que, en vez de replegarse sobre sí mismo o del narcisismo, apuesta por la apertura hacia el otro”36. De este modo, los masones "se encierran" para actuar mejor en el mundo, para constituir un laboratorio de perfección, una dimensión un tanto utópica de donde resurgirían hombres nuevos $^{37}$. Desde sus orígenes, entonces, el discurso masónico se organizaría según las modalidades de los otros religiosos, de los otros geográficos, del semejante, del mismo y de la inversión, principalmente, para distinguirse del común de los "profanos".

Sin embargo, remarca Beaurepaire en otro estudio ${ }^{38}$, la masonería no puede evitar mostrar sus preocupaciones y el arraigo de sus concepciones sociales y culturales. El discurso y el acto, según arguye, se alejan cuando se encuentra ante el otro absoluto, irreductible a un denominador común. En este sentido, el judío, el negro, pero sobre todo el musulmán, encarnarían el hándicap real para representarse ante el mundo como una familia de pares, de semejantes. Es decir, la vida harmoniosa en la comunidad correría peligro por la introducción de un cuerpo extraño inadmisible que no compartía los mismos valores culturales, sociales y morales que, en resumidas cuentas, se identificaban con el cristianismo y la civilización occidental. Y tal punto de inflexión vendría determinado por el discurso de Louis-François de la Tierce, pionero de la expansión de la orden en Europa ${ }^{39}$. Sus disquisiciones reflejaban, a este respecto, que,

para penetrar en el crisol que es el templo masónico, el solicitante que va a convertirse en un hombre nuevo y renacer con su iniciación, debe previamente poseer una compatibilidad con el grupo que se aprecia a recibirle. El mismo autor que aparecía como el celador de una masonería universalista, abierta al otro, a la diferencia, terminaría por limitarla ${ }^{40}$.

\footnotetext{
${ }^{35}$ Véase Céline Bryon-Portet, Sociologie de socieétés fermés. Imaginaire symbolique et sacralité en miieu clos (Montpellier : Presses universitaires de la Méditerranée, 2013).

36 "Ècole de la différence, la franc-maçonnerie est quête d'identité: elle apprend à chacun à se découvrir, à se construire individuellement, mais dans une démarche qui à l'inverse du repli sur soi, ou du narcissisme, fait le pari d l'ouverture aux autres" [mi traducción]. Pierre-Yves Beaurepaire, La république universelle des francsmaçons. De Newton à Metternich (Rennes: Ouest-France, 1999), 20.

${ }^{37}$ Bryon-Portet, Sociologie de socieétés fermés, 47.

38 “Pour pénétrer dans le creuset qu' est le temple maçonnique, l' impétrant qui va pourtant devenir un homme nouveau, renaître à l' occasion de son initiation, doit préalablement posséder une compatibilité avec le groupe qui s' apprête à le recevoir" [mi traducción]. Beaurepaire, "Perception et réception des musulmans dans les loges maçonniques du siècle des Lumières". Cahiers de l'Orient, (2016): 3.

${ }^{39}$ Joseph Uriot, Lettre d' un Franc-Maçon à M. De Vaux; conseiller de Sa Majesté le roi de Pologne, duc de Lorraine et de S.A.E. le comte palatin du Rhin, nouvelle édition, à Francfort-sur-le-Main, MDCXLIII, 16.

${ }^{40}$ Beaurepaire, "Perception et réception des musulmans", 3-4.
} 
La diferencia religiosa y, por extensión, cultural, se convierte así en una amenaza, conduciendo la profesión de fe universalista a la "delimitación de la universalidad" ${ }^{41}$ ". La comunidad se soldaba, por tanto, en dos sentidos, uno negativo, en oposición al otro, rechazándolo, y otro positivo, por el hecho de cultivar valores comunes. El elevado, el hermano no podía ser sino un semejante o un asimilado. En este sentido, el islam, el conjunto de la sociedad musulmana, sus miembros, sus valores y sus creencias, eran descalificados, relegados a las hordas de la civilización y ubicados en la barbarie. Una diferencia significativa, por ejemplo, a la iniciación de mujeres en las logias de adopción, puesto que, al fin y al cabo, estas pertenecían al mismo código sociocultural y religioso. En la Ilustración, donde surgen y se desarrollan las primeras logias masónicas bajo los preceptos de igualdad, universalidad, comunidad, etcétera, el miedo al otro se convertiría en obsesión $^{42}$. Los orientes y talleres situados donde existieron comunidades judías o puertos del mediterráneo, produjeron, de este modo, un discurso narrativo nutrido de medidas discriminatorias. Medidas que permiten comprender, bajo una perspectiva única, las contradicciones internas de la sociabilidad masónica y, que permiten también, sondear el imaginario sociocultural de sus protagonistas y desmontar los procesos de exclusión que inician, conducen y justifican. Y aunque esta narrativa carezca de homogeneidad en sentido estricto $^{43}$, concluye en un rechazo sistemático —al menos inicial—de musulmanes por los masones europeos de este periodo.

En el siglo XIX, en una ya avanzada modernidad y a las puertas del colonialismo y el imperialismo por los diferentes territorios afroasiáticos, la consideración del otro musulmán cambiaría significativamente. Sin poder desprenderse, no obstante, de su condición de superioridad, la orden asumiría los mismos preceptos del canon colonial: se racializa y racializa, se autodefine como agente civilizador de los pueblos bárbaros y salvajes, como institución capaz de cambiar y mejorar su destino primitivo. Y los masones occidentales europeos, a su vez, se autoafirmarían como el modelo más perfecto e idóneo para llevar a cabo esta misión. La construcción del otro musulmán en este proceso, por consiguiente, adquirió nuevos significados. Si bien, partió desde las mismas tesis colonialistas, por "el bien del imperio"—o los imperios-debía adoctrinare o asimilar al sujeto colonizado. Y tal acción solo podía desarrollarse a través de dos formas: por un lado, desde su inclusión en las logias (aunque esto supusiese algunos inconvenientes a priori) y, por otro, mediante acciones civilizadoras de los talleres en la colonia, ya fuese por medio de proyectos educativos, actos culturales o conmemoraciones, como frenando directamente el peso de las misiones católicas y las políticas administrativas, económicas y sociales

\footnotetext{
${ }^{41}$ Beaurepaire, "Perception et réception des musulmans", 4.

${ }^{42}$ Beaurepaire, "Perception et réception des musulmans", 2.

${ }^{43}$ Beaurepaire habla de una "percepción dicotómica" de una masonería insular universalmente tolerante y otra continental que erigiría la discriminación como dogma. Beaurepaire, "Perception et réception des musulmans", 8 .
} 
desfavorables hacia los autóctonos. El miedo a la diferencia se diluía en el más absoluto paternalismo de la masonería. Esto significaba, a grandes rasgos, que el salvajismo, condición incuestionable de las poblaciones colonizadas, podía ser corregido por los agentes civilizadores de los talleres masónicos ${ }^{44}$. El ideal universalista parecía, de este modo, nuevamente posible.

Georges Odo, tildando en sus estudios a la masonería colonial francesa de un "espíritu misionero" ${ }^{45}$, ha establecido varios marcos de referencia que posibilitaron y beneficiaron la inclusión del musulmán en los talleres franceses establecidos en los dominios coloniales africanos: la asimilación y el "colonialismo humanista" 46. Ambos postulados, en plena sintonía, se desarrollaron a partir de la premisa básica de que el deber del colonizador era, sobre todo, educar a las poblaciones autóctonas, pues solo así se podía aceptar el derecho arrogado por las naciones occidentales de colonizar los pueblos que aún no habían alcanzado la civilización. Esta labor educativa, no obstante, resultaba más bien un "adoctrinamiento" 47 automático de tales poblaciones, que abarcaría todo el periodo colonial.

De este modo, los estudios de Odo establecen que la moral evangélica, inherente en los principios originarios de la orden, es decir, aquellos principios constitutivos que le impedían adherirse a ninguna iglesia, impregnan el discurso masónico en su sentido más universalista, mientras que, en la masonería colonial, hasta 1870, al contrario que su predecesora ilustrada, trascendería en el espacio y el tiempo permitiendo a otras confesiones religiosas instruirse en sus misterios, lo que significaba, en África, amalgamar a los árabes, a los bereberes, a los judíos y a los cristianos. La asimilación que esto implicaba es, a los ojos de los masones, la civilización y, por consecuencia, el único motivo legítimo de la ocupación ${ }^{48}$. La aceptación de la iniciación del primer musulmán ${ }^{49}$, dictada desde 1839 en Algeria, respondía a esta política: los posibles candidatos indígenas para su inclusión en los talleres debían conocer la lengua francesa, el árabe, y, además, debían jugar un rol importante en la colonia. Y, llegado el caso de que fuesen muy numerosos los asimilados, podría existir la posibilidad de constituir una logia exclusivamente indígena, tal y como propondrían también los masones españoles en su zona de protectorado.

\footnotetext{
${ }^{44}$ Sá, "La construcción del indígena", 97.

${ }^{45}$ Georges Odo, La Franc-maçonnerie dans les colonies, 1738-1960 (París: Éditions Maçonniques de France, 2001), 90.

${ }^{46}$ Según este autor, los francmasones se suman a la idea central de que la colonización era esencialmente la creación de humanidad, y este enriquecimiento debe basarse en la asociación de las razas que el colonizador gobierna, y que debe aumentar su valor humano. Odo, La Franc-maçonnerie en Afrique, 1781-1960 (París: Éditions Maçonniques de France, 2001), 45-48.

${ }^{47}$ Beaureapaire, "Perception et réception des musulmans", 12.

${ }^{48}$ Odo, La Franc-maçonnerie en Afrique, 50-52.

${ }^{49}$ Sidi Hamed por Les Frères Numides de Bougie. Georges Odo, La Franc-maçonnerie en Afrique, 51.
} 
Por otra parte, el colonialismo humanista que las logias francesas emprendieron en sus diferentes colonias, descansaba en un doble plan de actuación, un plan material y otro moral. La obra material consistió en mejorar el estado fisiológico de las poblaciones a través del favorecimiento de una alimentación sana y suficiente, una higiene apropiada, medicamentos, hospitales, orfanatos, sociedades de pensiones, mutuas y otros sistemas de seguridad social. Y la obra moral, residió en plantear reformas políticas y educativas que, posteriormente y de forma paulatina, permitiese alcanzar la asimilación progresiva de los autóctonos: instrucción del indígena, instrucción de la mujer, revisión de la reglamentación del trabajo injusto, el deseo de representación real en el Parlamento francés (esto en el caso argelino), etcétera. En 1927, esta obra moral se había traducido en una lucha más potente por parte de la Gran Logia de Francia $^{50}$ : mejoras en la instrucción de los indígenas, la aplicación de leyes sociales más justas, la reorganización de la vida comunal en detrimento de los territorios militares, el apoyo a las obras laicas y no tanto a las misiones religiosas y la supresión del código del indigenato.

No obstante, siguiendo la trayectoria cronológica establecida por Odo, después de 1870, la laicidad y el librepensamiento impregnaron la ideología masónica hasta tal punto, que derivaría, irremisiblemente, en un marcado carácter anticlerical y antirreligioso, muchas veces interpretado como fundamentalismo y ortodoxia. Esto se plasmaría en un escrutinio mucho mayor a la hora iniciar musulmanes, pues también se empezaba a restringir la entrada a aquellos que hubiesen adquirido o asimilado la civilización occidental. La nueva exclusión del "otro" nacía, en estos momentos, del pujante nacionalismo que surgía con fuerza en la franja norteafricana. A pesar de ello, la presencia de muchos musulmanes era interpretada como una prueba de esperanza y de confianza en su "perfectibilidad" 51 ".

Con todo, el colonialismo humanista de los masones franceses nunca se materializaría: la inestabilidad de las colonias por el descontento de la ocupación occidental, las guerras del Rif en Marruecos y la configuración de los nacionalismos autóctonos, sobre todo el marroquí, limitarían y delimitarían este discurso hasta el punto de que, algunos masones de la zona española, denunciaron que no se estaban iniciando musulmanes en los talleres del protectorado francés ${ }^{52}$. Y es que, de todas las medidas adoptadas por esta masonería, las logias, en ninguna ocasión, pusieron en entredicho el principio de la colonización. Y quizás, la mayor prueba de ello sería la actitud tomada hacia el nacionalismo de los territorios coloniales, especialmente, en el Magreb. Los nacionalistas marroquíes insertos en las logias masónicas, sobre todo en la zona española, donde tenían mayor flexibilidad después del advenimiento de la II República, socializaban y trabajan en

\footnotetext{
${ }^{50}$ Odo, La Franc-maçonnerie en Afrique, 46.

${ }^{51}$ Odo, La Franc-maçonnerie en Afrique, 55.

${ }^{52}$ Expediente de la Gran Logia de Marruecos. CDMH, SE Masonería A L. 499.
} 
ellas sin que su posicionamiento político pudiese ser, a priori, un elemento perturbador en la cohesión de los talleres. Si bien trataremos este problema con mayor profundidad en el último apartado del trabajo, debemos remarcar el hecho de que el surgimiento del nacionalismo marroquí-y otros nacionalismos coloniales-conformados bajo los preceptos del islam en un sentido sociocultural, fue un punto de inflexión en la masonería colonial francesa, al igual que lo sería en la española, aunque ambas tomasen diferentes posicionamientos. El islam se presentaba como una nacionalidad religiosa, donde el credo y la sociedad estaban íntimamente ligadas. Esto significaba que la integración en la sociedad europea por parte de sus miembros se convertía, irremediablemente, en una abjuración del mundo musulmán. Dicho de otro modo, tal dicotomía parece ser una de las causas de la ausencia de musulmanes en las logias francesas en este periodo previo a 1945 y a la independencia de las colonias. El rechazo partía a su vez, de la sujeción de los europeos a la razón y de la fidelidad de los musulmanes a su religión ${ }^{53}$. Pero volveremos a ello más adelante.

No será hasta 1939, cuando los talleres franceses tomen verdadero partido ante lo inevitable de la situación suscitada en sus colonias. $\mathrm{Y}$ es que, hasta ese momento, no terminaron de comprender que, en sus dominios coloniales, cohabitaban dos sociedades sin ningún tipo de interrelación real, los protectores y los protegidos. Sin embargo, este periodo, que marca el comienzo de la Segunda Guerra Mundial y el inicio de la descolonización de los territorios protegidos, queda fuera de nuestro rango de estudio, precisamente porque en esas fechas la masonería española no solo había dejado de actuar dentro de los límites nacionales, sino que estaba siendo fuertemente reprimida y represaliada. Sus discursos coloniales y al respecto de la alteridad musulmana y marroquí no tenían razón de ser cuando lo que estaba en peligro era su propia existencia.

En definitiva, y de acuerdo con Beaureapire, los masones han sido-y sonhombres de su tiempo. Hombres que, al fin y al cabo, no pudieron abandonar totalmente sus prejuicios profanos a las puertas del templo ${ }^{54}$. Los estudios de los discursos normativos, las prácticas discriminatorias, el difícil diálogo entre el otro y el semejante, permite al historiador sondear las mentalidades temporales, reconstruir el miedo del otro, su arraigo y sus líneas de fuerza. Estudiando cómo se estructura la identidad masónica, se percibe que, lejos de eliminar las otras identidades - profanas, religiosas, nacionales, etcétera-, las cruza, aunque no sin contradicciones ni fricciones. Y si se acomoda a veces, no ignora jamás, aquello que decían los hijos de Hiram. La mejor prueba de ello reside en la actuación colonial de las logias españolas en la zona de $s u$ protectorado, tal y como veremos a continuación.

\footnotetext{
${ }^{53}$ Odo, La Franc-maçonnerie en Afrique, 56.

${ }^{54}$ Beaureapaire, "Perception et réception des musulmans", 18.
} 


\section{El hermano moro y los masones españoles}

En los anteriores apartados, siguiendo a diferentes especialistas, hemos intentado realizar un esbozo de las variables contextuales y conceptuales, tanto masónicas como no masónicas, que pudieron intervenir y condicionar la construcción y percepción del otro musulmán por los masones españoles de las logias norteafricanas. Partiendo de ello, en las líneas que siguen abordaremos de forma específica la particularidad del discurso conformado por la masonería española en África, sus percepciones en torno a la alteridad, y todos aquellos elementos que explican o definen su composición y desarrollo. Sin olvidar que tales variables, por extensión, produjeron y motivaron diferentes identidades ex professo: ser español, ser moro, ser musulmán, ser masón y, por supuesto, ser masón musulmán. En último lugar, pero desde un sentido inverso, abordaremos también hasta qué punto dicho discurso determinó no solo la inclusión o exclusión de los musulmanes en las logias, sino la propia percepción de estos últimos sobre su "condición masónica" a lo largo de esta historia interminable de construcciones y reconstrucciones de identidades individuales, colectivas y nacionales.

En estudios anteriores, ya hemos analizado las particularidades del discurso masónico en el Protectorado español de Marruecos, definiéndolo bajo el triple concepto de "ideal masónico colonial ${ }^{55 "}$. Este ideal, producto del imaginario cultural español y el imaginario masónico preexistente en y consustancial a los preceptos y estamentos de la orden, producto subyacente, además, de la modernidad en la que se establece y constituye la masonería en sus primeros pasos "especulativos", acabaría derivando en un proyecto colonizador y cosmopolitizador ${ }^{56}$ en aquellos territorios no europeos ni identificados como la civilización occidental. En definitiva, en el Norte de África.

Si bien los elementos establecidos en la configuración de dicho discurso, partieron de la identidad española y de España como nación, los errores y abusos de la primera situación colonial (incluidos los masónicos) que desembocarían en la pérdida de las colonias de ultramar, también estuvieron motivados por el destino cuasi-divino de la masonería española para redimir, regenerar y reconciliar los errores de la nación y, por consiguiente, crear o configurar una sociedad pura - y utópica-desde sus preceptos. Una sociedad ideal que re-significaba Marruecos como un nuevo Al-Ándalus de convivencia intercultural. Un imaginario, al fin y al cabo, configurado implícitamente para legitimar y justificar no solo su poder colonialista en África, sino para erigirse como institución capaz de influenciar, cambiar y mejorar el destino político-social de su país y el que se encuentra bajo su protección y, con ello, cambiar y mejorar la identidad de su propia nación ${ }^{57}$. Es

\footnotetext{
${ }^{55}$ Aguiar Bobet, "En busca de la colonia perfecta".

${ }^{56}$ Aguiar Bobet, "La masonería española en el protectorado marroquí".

${ }^{57}$ Aguiar, "En busca de la colonia perfecta".
} 
suficientemente representativo a este respecto, el texto publicado por el Boletín del Gran Oriente Español en 1926, indicando que la masonería

como no se considera depositaria de una verdad superior que se deba imponer a los hombres, sino que aspira tan solo a crear o desarrollar en ellos el espíritu de fraternidad, es singularmente apta para las empresas políticas que tienen como finalidad primordial la de elevar espiritualmente a los pueblos degradados o infantiles. Por eso su inmensa utilidad social en las avanzadas que las naciones europeas sostienen en África, Asia y Oceanía. Por eso el afán de la administración francesa en facilitar la labor de las logias coloniales ${ }^{58}$.

A diferencia de las narrativas de la hermandad hispano-magrebí y la comunidad de sangre para lograr un presente y un futuro mejor de la nación durante el periodo autárquico del franquismo, que más bien escondía el deseo de estabilizar el régimen con el beneplácito y el apoyo de los habitantes del protectorado durante la dura posguerra ${ }^{59}$; a diferencia además, de la política indiferente y poco concluyente de la República y los regímenes anteriores a ella, la masonería norteafricana, en su resignificación del pasado, pretendía construir, desde los preceptos universalistas, cosmopolitas y laicistas que le eran inherentes, un verdadero crisol de culturas ${ }^{60}$. En este crisol, en el que Marruecos se presentaba como un diamante en bruto lo suficientemente plástico para poder adoctrinarse en términos de Beaurepaire, los judíos, musulmanes y cristianos podrían vivir sin diferenciación ni distinción cultural, sociopolítica o religiosa. Así mismo lo instituía el Gran Maestre del Gran Oriente Español y Ministro de Comunicaciones durante la II República, Diego Martínez Barrio, en sus declaraciones a Oriente no. 451 de Tetuán, pues era "precisamente en Marruecos donde mayor labor puede hacerse por la Masonería", ya que "los sentimientos de fraternidad en ninguna parte se pueden demostrar mejor que en aquellos países privilegiados en que conviven árabes, españoles y hebreos ${ }^{61}$ ".

No obstante, el crisol de culturas encerraba varias condiciones procedentes, precisamente, del proyecto cosmopolitizador de la masonería. Es decir, su pretensión

\footnotetext{
58 "Digno de estudio. Sobre la masonería francesa en África”, Boletín del Gran Oriente Español I, no. 1 (10 de octubre de 1926): 4-6. Este mismo artículo fue publicado en un boletín posterior del mismo Gran Oriente, II no. 5 (10 de febrero de 1927).

59 De sobra conocida es la alianza de los nacionales con los marroquíes durante la guerra civil, en parte motivada por la indiferencia de la República hacia el protectorado y hacia las demandas de los nacionalistas marroquíes. Véase, por ejemplo, Yolanda Aixelà Cabré, "Imazighen y árabes del Protectorado español”, 2192.

${ }^{60}$ El término "crisol" en este caso, fue acuñado por primera vez por Manuel de Paz, "España, Cuba y Marruecos: masonería, identidades y construcción nacional”, Anuario de Estudio Atlánticos 55 (2009): 273310 .

${ }^{61}$ Tenida de Oriente no. 451 el 16 de abril de 1932. CDMH, SE Masonería A, L. 401.
} 
esencial se basaba en la mezcla (forzosa) de culturas ${ }^{62}$, pero una mezcla que, si bien patrocinó la armonía humana por encima de fronteras culturales y nacionales, siempre lo hizo desde la acción colonizadora. La búsqueda ulterior tenía como fin la perfecta unificación cosmopolita del espacio colonial y el establecimiento de un orden común ${ }^{63}$ impuesto desde la institución, los preceptos masónicos y el imaginario colonial. En este sentido, presentaba un código ético, moral que, sin saberlo, incluía la noción de multiculturalismo, pero no una noción intercultural: todas las culturas tendrían los mismos derechos y deberes desde un punto de vista jurídico masónico siempre y cuando los elementos que configurasen sus individualidades no entrasen en contradicción con la manera en que los miembros de la orden asumían su propia identidad masónica y española. El código ético del proyecto cosmopolita masónico incluía otros principios, inherentes a la propia condición del "ser masón", es decir, sin los cuales un individuo no puede ser iniciado en sus secretos: el deseo de perfeccionamiento humano a través del estudio, la primacía del uso de la razón, la autorrealización individual, una moral y virtud intachables, la preocupación por el bienestar de la sociedad y del otro, en definitiva, el perfeccionamiento individual y no solo el perfeccionamiento político y social de la humanidad en general. Pero, también, incluía la noción del deber. El deber masónico que, en este contexto colonial, entre otros aspectos, implicaba cumplir la "alta misión" (cosmopolitizar) tan mencionada en los reglamentos de las logias, que había sido encomendada a España y a la masonería. Martínez Barrios, de nuevo, ilustró a la perfección estas premisas, con motivo de su visita de inspección de los talleres norteafricanos, al referirse en su disertación a los pueblos musulmanes como "degradados" y envilecidos" que simplemente necesitaban de

la obra abnegada del colonismo inteligente, y desde luego, la única posible de la Masonería. Nuestros Talleres tienen que convertirse en laboratorios donde se amalgamen los diferentes postulados de tales pueblos en crisis, para producir un nuevo tipo de civilización marroquí, que iguale o supere a aquel otro de tiempos pretéritos en el que fundan, hoy mismo, su orgullo y su ilusión. Ni en Casablanca, ni en Tánger, hay todavía hh.: moros, en los Talleres, seguramente, a consecuencia de una norma de conducta que las Logias se vienen marcando; y es ello condenable injusticia de la que nos debemos purgar ${ }^{64}$.

Ya hemos mencionado que, durante los años 30 tampoco se iniciaba a musulmanes en los talleres marroquíes de la zona francesa, hecho denunciado por un miembro marroquí

\footnotetext{
${ }^{62}$ Jefferson Jaramillo Marín, "Cosmopolitismo(s) y modernidade(s)", Diálogo de saberes 29 (julio-diciembre 2008): 191.

${ }^{63}$ Jaramillo Marín, "Cosmopolitismo(s) y modernidade(s)", 180.

64 "La visita de Martínez Barrios a los talleres de Marruecos", Boletín del Gran Oriente Español, año II, no. 15 (10 de diciembre de 1927): 5-15.
} 
de Oriente no. 451 de Tetuán ${ }^{65}$. En el protectorado español, al contrario, “era esencial” su inclusión, por ser el único modo de cumplir su "alta misión”. Las cifras demuestran que, al menos, 27 musulmanes se contabilizaron en las logias españolas durante el periodo republicano de los 1000 masones que, aproximadamente, se calculan para este periodo ${ }^{66}$. La mayoría se localizaron en Tetuán y Larache, las dos plazas que mayor actividad masónica presentaron en este cómputo temporal. No disponemos de datos suficientes para los años precedentes a la Segunda República, pero si tenemos constancia de la perpetua participación de musulmanes marroquíes desde las primeras logias españolas implantadas en el territorio marroquí en la última década del siglo XIX, especialmente en la ciudad tangerina. La razón era obvia, Tánger presentaba mayor protagonismo político ${ }^{67}$ antes de oficializarse el protectorado en su sede tetuaní. Albergaba a la mayoría de europeos y americanos como zona geoestratégica y comercial. En ella residían numerosos talleres masónicos franceses, ingleses y españoles, de los que destacaban estos últimos por su mayor actividad $^{68}$. Además, la mayoría musulmana y judía de uno de los primeros talleres constituidos en la plaza tangerina, Luz de Marruecos ${ }^{69}$, indicaba la gran importancia del componente marroquí entre sus cuadros. Asimismo, en los expedientes personales que hemos consultado sobre los masones musulmanes del periodo republicano, se puede comprobar que, muchos de ellos, se iniciaron en las primeras décadas del siglo XX y que, su condición de "durmientes" se había debido, entre otras cosas, a la propia inestabilidad que aún presentaba el territorio colonial y a las persecuciones por parte de las autoridades civiles y militares que sufrió la orden en general.

De todos modos, a pesar de esta constante permanencia, el número de componentes siempre fue escaso, sobre todo, teniendo en cuenta que eran la mayoría de la población. Los masones españoles no podían obviar las barreras y hándicaps que, tanto su ideal masónico colonial como su proyecto cosmopolitizador atravesarían por las percepciones y consideraciones que encerraba para ellos la mayoría de la población, los musulmanes: la inmadurez cívica subyacente en los indígenas, la religión islámica, la precaria o inexistente educación, la lengua árabe, el nacionalismo marroquí desarrollado durante las primeras décadas del siglo XX y, con todo, los estereotipos heredados a partir de las distorsiones de los discursos de identificación nacional española (desconfianza, traición, etcétera), de los

\footnotetext{
${ }^{65}$ A. Bennuna, en tenida de la Gran Logia de Marruecos de 1 de mayo de 1933, recomienda iniciar a musulmanes de Arcila ya que en aquellos valles se están persiguiendo a algunos de ellos, a lo que el gran orador, Hossain Mohamed Hehe añade que en las logias francesas se prohíbe iniciar a musulmanes, proponiendo acabar con tal prohibición. CDMH, SE Masonería A, L. 499.

${ }^{66} \mathrm{Se}$ conservan varios registros e inventarios franquistas que contienen diferentes listas de los masones del protectorado español. Hemos tomado como referencia uno de los últimos de 1 de diciembre de 1936. CDMH, SE Masonería A, L. 390.

${ }^{67}$ Moga Romero, Al oriente de África, 74-75.

${ }^{68}$ Odo, La franc-maçonnerie dans les colonies, 60.

${ }^{69}$ En su cuadro lógico de 9 de diciembre de 1891. CDMH, SE Masonería A, L. 605 E. 8.
} 
que muchos masones no pudieron desprenderse. Y es que el escrutinio y la selección de aquellos "indígenas que se hallan en condiciones" "70 de iniciarse a la masonería, se reducía estrepitosamente por las representaciones racializadas e infantilizadas que comentamos al inicio de este trabajo:

el moro y más aún el que nutre la recluta de estas Fuerzas Jalifianas, es como un niño, pero un niño grande, en el que es más fácil hacerle discernir entre lo que es provechoso y lo nocivo: siente hasta en lo más íntimo las injusticias que con él cometan, por eso, una de las formas en que nos debemos acercar a él, es practicando la justicia en todos sus órdenes, a la par que inculcarles su amor por instruirse (...), y formar así una nueva generación propicia para recoger toda la enseñanza de una civilización que les abre de par en par las puertas hacia la cultura y el progreso ${ }^{71}$.

Con esta constante discursiva al respecto de la población magrebí, la cohesión de la comunidad se traducía, al igual que sucedía en la masonería francesa, en un concepto concreto de quién o quiénes podían llegar a ser masones. En los informes de solicitud de inicio a los diferentes talleres masónicos del Magreb, se matizaba perfectamente esta selección: la formación intelectual, la alta o media inteligencia que presentaban los solicitantes, contrarrestando así el peso de la niñez implícita en la raza. También se precisaba que debían conocer la lengua española y, además, tener cierta importancia política, económica y religiosa o, según sus términos, poseer "gran prestigio entre el elemento musulmán ${ }^{72, "}$. Y en todos los casos, sin excepción, los afiliados no solo conocían el español y el árabe, sino el francés y el hebreo, del mismo modo que tenían profesiones relevantes dentro de la administración, ya fuese la española o la propia del Majzén (caídes, militares, funcionarios diversos como ministros, maestros, intérpretes, policías, etcétera).

En definitiva, se trataba de la misma política de asimilación que proyectaban las logias francesas en la zona sur de Marruecos, pero con una salvedad, evidenciando que aquellas barreras socioculturales de los sujetos colonizados que les impedía llegar a los límites prestablecidos, podían corregirse. Prueba de ello son las continuas alusiones que hacen referencia a su educación, profesión, a su autoformación o deseo de mejoramiento, con premisas como "hijo de familia modesta. Su padre es herrero y él con su esfuerzo

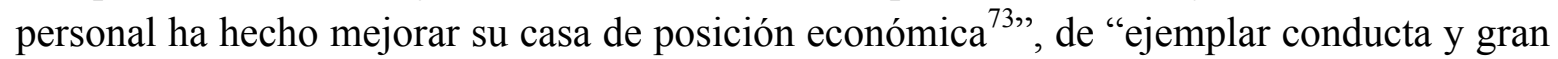
deseo de aprender ${ }^{74,}$, entre otras. Dicho de otro modo, aquellos elegidos que podían estar

\footnotetext{
${ }^{70}$ Ramiro Farpón Pumariega a su taller, Cabo Espartel, agosto de 1933. CDMH, SE Masonería, A L. 115 E. 11.

${ }^{71}$ Así lo induce José Suárez Álvarez en una carta a la logia 14 de Abril no. 450 de Melilla, 17 de noviembre de 1933. CDMH, SE Masonería A, L. 26 E. 17.

${ }^{72}$ Mohamed Ben Abdelkader Ben Muza. CDMH, SE Masonería A, L. 95 E. 21.

${ }^{73}$ Buker Tetuani Abd-El-Kader Ben. CDMH, SE Masonería A, L. 95 E. 8.

${ }^{74}$ Mohamed Ben Abderrahamán Fajar. CDMH, SE Masonería A, L. 32 E. 4.
} 
en condiciones de ser iniciados en la masonería debían ser, en cierto modo, librepensadores, autónomos con respecto a su contexto, pero, sobre todo, debían querer cambiar, "mejorar" o ser lo suficientemente maleables para ello. Preferiblemente, por supuesto, bajo los cánones eurocéntricos de su ideal colonial. Así en otro informe, se valoraba positivamente que el solicitante tuviera "apariencia europea" del mismo modo que era "un elemento dúctil y fácil de ser perfeccionado"75. Y dentro de la sociedad marroquí, esto se traducía en que solo podían ser iniciados aquellos individuos que simpatizaban con la protección española:

desde luego, es un marroquí, adicto desde un principio, a la causa de España, por la que se ha batido, mucho y bien. Moralidad relativa, lo que, a juicio del informante, no es moralidad buena ni mala. Es que entiende la moralidad, como la entiende el $90 \%$ de los musulmanes de la zona" ${ }^{, 76}$. Del mismo modo, en otra valoración suya se puntualizaba que "en su vida pública y privada está muy bien considerado. Moralidad respecto a su modo de vivir; excelente, ¿Moralidad en todos sus actos? ¡Según como se mire! Visto con nuestros ojos, fue un poco inmoral por la forma de sacar dinero explotando al de abajo. Teniendo en cuenta las costumbres del país, no es inmoral ${ }^{77}$.

En este sentido, la cuestión no radicaba en que su moralidad "marroquí" o su religión "musulmana" fuese acorde a los preceptos de la masonería o no, a sus principios más arraigados, sino que, además de ser "adicto a la causa de España", sus inconvenientes morales no eran demasiados exagerados o inmutables hasta el punto de condicionar el orden, la cohesión de los talleres y su proyecto ideal.

No obstante, el discurso racializante era implacable, pues la aceptación de la diferencia cultural siempre se estimaba desde la identidad musulmana. Es decir, desde un sentido religioso y cultural, heredado y proveniente de la construcción invariable y cosificadora de la identidad del "moro" por los españoles. El "moro", de esta forma, se identificaba, únicamente, con lo musulmán, sin apreciar ni distinguir que, dentro de este grupo religioso, había diferentes ramas étnicas. En el ámbito político español, esta concepción reduccionista formaba parte de una estrategia concreta, denominada por Yolanda Aixelà Cabré bajo el término de "marroquinidad" 78 ", que se erigía sobre el deseo de primar la identidad nacional marroquí, suavizando la división étnica con una praxis jurídico-política que relativizaba la centralidad de lo musulmán, de lo árabe y de lo amazigh (bereber) en el protectorado y que, además, acabaría propiciando, sin pretenderlo

\footnotetext{
${ }^{75}$ Mohamed Ben Layasi Zel-Lal. CDMH, SE Masonería A, L. 32 E. 5.

${ }^{76}$ Hossain Ben Mohamed Hehe. CDMH, SE Masonería A, L. 95 E. 16.

${ }^{77}$ Hossain Ben Mohamed Hehe. CDMH, SE Masonería A, L. 95 E. 16.

${ }^{78}$ Yolanda Aixelà Cabré, "Imazighen y árabes del Protectorado español. Una revisión de la construcción nacional del Marruecos contemporáneo”, en Tras las huellas del colonialismo español en Marruecos y en Guinea Ecuatorial, coord. Yolanda Aixelà Cabré et al (Madrid: CSIC, 2015), 23-24.
} 
(al contrario que el estado francés que evocó la política divide et imperas ${ }^{79}$ ), la lucha común de árabes e imazighen contra la presencia colonial hispano-francesa. En cambio, en las logias, el punto más álgido de este reduccionismo hacia lo marroquí y musulmán, sin asumir la heterogeneidad de la población que pretendían cosmopolitizar, se representa en una escasa o inexistente mención en los documentos producidos por las logias, ni siquiera por los masones musulmanes. Prueba quizás, de que su identidad se acomodaba a la ignorancia o desconocimiento de los españoles respecto a sus particularidades como nación, o bien por considerar que esta escasa atención a la diferencia étnica permitía una mayor autonomía y un mayor autocontrol de su país. En este último caso, podemos reafirmar cómo el colonialismo español gozaba de mayores simpatías que el francés precisamente por su flexibilidad y heterodoxia. Los mismos masones musulmanes, de igual forma que "entendían" el paternalismo español, denunciaban constantemente el imperialismo francés ${ }^{80}$.

En definitiva, a pesar de la existencia de estas barreras conceptuales para llevar a cabo su alta misión, las logias españolas de Marruecos, no se apoyaron únicamente en la asimilación o en un tipo de colonialismo humanista según la terminología expresada por Georges Odo, sino en una cierta "cultura de la tolerancia" ${ }^{81}$, intrínseca en su proyecto cosmopolitizador y su ideal masónico colonial. En este sentido, no solo se promulgaron políticas civilizatorias comunes como cetros educativos laicistas para los tres grupos, se concedieron becas a estudiantes marroquíes, se instituyó el Ateneo Hispano Marroqui ${ }^{82}$ o se animó constantemente a la constitución de logias en zonas rurales con menor población colonizadora, primando así la inclusión de los marroquíes que allí habitasen; sino que el proyecto también incluyó diferentes propuestas directamente relacionadas con la tolerancia de la alteridad. El concepto de tolerancia equivaldría aquí, además de a su definición genérica ("respeto a las ideas, creencias o prácticas de los demás cuando son diferentes o contrarias a las propias" ${ }^{, 83}$ ), a otro significado más preciso. Tolerar suponía permitir algo que no se tenía por lícito, sin aprobación expresa ${ }^{84}$. Es decir, la actuación y proyección masónica de la masonería española en el Magreb se basó en una relativa aceptación de la diferencia, una relativa permisión de la diferencia del otro, que, si bien se distinguiría de

\footnotetext{
${ }^{79}$ Aixelà Cabré, "Imazighen y árabes", 21-59.

${ }^{80}$ Existen numerosa correspondencia que lo ilustra. Por ejemplo, la carta de la logia Alfa no. 80 a Gran Logia de Marruecos, que protesta por la injusta expulsión de A. Bennuna de la zona francesa, solicitando ponerse en contacto con el Gran Oriente Francés por esta forma de proceder, probablemente por su relación con el movimiento nacionalista, 31de marzo de 1933. CDMH SE Masonería A, L. 95 E. 15.

${ }^{81}$ Véase Aguiar Bobet, "La cultura de la tolerancia".

${ }^{82}$ Carta de la Gran Logia de Marruecos al Gran Consejo Federal Simbólico del Gran Oriente Español, 15 de febrero de 1933. SE Masonería A, Leg. 499.

83 "Tolerancia", Diccionario de la Real Academia Española, http://dle.rae.es/?id=ZyWPzRW

84 “Tolerar", Diccionario de la Real Academia Española, http://dle.rae.es/?id=ZyZDjRx
} 
otros agentes civilizatorios, sobre todo, de la masonería francesa, en ningún caso, fue una tolerancia completa.

Las logias españolas "permitieron" y "aceptaron" ciertas diferencias que en otros momentos de su historia hubiesen sido inadmisibles. Y su máximo denominador fue la inclusión de musulmanes a pesar de la práctica de su religión, a pesar de su condición nacionalista y a pesar de los estereotipos de su "morosidad". Prueba de ello, también, fueron las iniciativas de la publicación de folletos y otras obras masónicas en árabe, la existencia de intérpretes en sus filas, la posibilidad de realizar la promesa masónica sin recurrir a ningún texto sagrado, para que no se malinterpretasen "las preferencias inexistentes de la orden" e incluso la eventualidad de efectuarla sobre el Corán ${ }^{85}$. Aunque ninguna de ellas llegaría a materializarse. Sin embargo, las continuas discusiones sobre las variables condicionantes de los sujetos colonizados en los talleres son una muestra significativa del debate en torno a la influencia y el papel de la masonería en la construcción y reconstrucción de su comunidad intercultural y, por extensión, del papel individual que los masones tendrían respecto a la portación de civilización y la configuración de las identidades colonizadas conforme a sus preceptos. Es decir, una vez fuesen adiestrados cultural y socialmente por esta. Los mayores obstáculos residían, en última instancia, en cuestionar la protección española y los principios eurocéntricos de la cosmopolitización y civilización: el progreso de la civilización occidental, el universalismo, la secularización de la vida cívica (en detrimento de la religiosa) o bien ir en contra de su alta misión.

\section{Política y religión, ¿paradigmas insondables?}

Las variables que condicionaron de forma más significativa la percepción, asunción y tolerancia del musulmán como masón, más allá del lenguaje, de su formación educativa, de su cultura y moralidad y de su importancia política o económica en el protectorado, fueron las ideas religiosas y las ideas políticas de los solicitantes, muchas de las cuales supusieron, al final, un balotaje negativo en el escrutinio de los talleres. No obstante, diferenciando sus recorridos, observamos que las ideas religiosas, sean cuales fuera, en ningún caso implicaron el rechazo de la orden. Es más, en la casi totalidad de los informes disponibles se hace alusión a las ideas religiosas musulmanas de los marroquíes sin ningún tipo de reservas. Sin embargo, siempre matizaban la inexistencia del "fanatismo" en su práctica, al igual que sucedía con los cristianos y los judíos ${ }^{86}$. De hecho, en varios de estos informes se especifica que el candidato no practicaba la religión o bien, carecía de la

\footnotetext{
${ }^{85}$ Actas de Atlántida no. 448 de 12 de junio de 1931 y de la Gran Logia de Marruecos, el 10 de febrero de 1933. CDMH, SE Masonería A, L. 404 y 499.

${ }^{86}$ Aguiar Bobet, "La cultura de la tolerancia".
} 
misma. Lo instituían en los siguientes términos: "no creo que practique la religión musulmana. Por conversaciones mantenidas con él sobre este tema he sacado la consecuencia de que admite la existencia de un poder supremo pero no está de acuerdo con ninguna clase de culto" ${ }^{, 87}$. A pesar de ello, en otro informe perteneciente al mismo individuo evaluado, realizado esta vez por un masón musulmán, se puntualizaba que sí practicaba "el islamismo" pero, sin fanatismos", pues era "tolerante" con las "demás religiones ${ }^{88}$.

Como vemos, la práctica más devota de la religión islámica, se presentaba como el gran dilema, sobre todo porque llevaba parejo la asunción estereotipada de los cristianos, quienes confundían el desconocimiento de esta religión-y de la cultura islámica en general - con el fanatismo y el panislamismo. Un ejemplo de ello es el informe de Tomás de Lora sobre un musulmán al que su comunidad consideraba como una especie de "santo" y que, según su criterio, podía llegar a formar "hombres fanáticos en el rito que practica",89, aunque concluyese, al final, que no era "indigno de ingresar en la Orden", pero que tampoco "era conveniente". Junto a esta valoración, sin embargo, Hossain Ben Mohamed Hehe, establecía unas disertaciones muy distintas sobre el mismo individuo: "es hombre liberal aunque constantemente lleva consigo y a la vista rosarios y símbolos religiosos"90.

Las valoraciones cambiaban en función del informante y de su percepción de la religión. El baremo era distinto por el mero hecho de lo que significaba en sus vidas el credo en cuestión: para la mayoría de los musulmanes no existía una clara diferenciación entre la vida religiosa y la vida secular o civil, mientras que para los masones, laicos y anticlericales per se, la profesión de fe y la vida pública o, en este caso, masónica, no coincidían en ningún punto. En este sentido, no debemos obviar que la presencia musulmana en Europa ha sido relacionada con una parte de la construcción política del conflicto de civilizaciones. Del mismo modo que el multiculturalismo en España se ha definido como un conflicto, a su vez, entre modelos de sociedad (una occidental y la otra, musulmana), que son incompatibles ${ }^{91}$. Desde una perspectiva religiosa, la contradicción se originaba, entonces, en la vida relativamente secularizada del pueblo español y la omnipresencia del islam en la del marroquí. Lo que creaba tal conflicto era el papel de la religión en la sociedad, y especialmente la representación de la religión en el espacio

\footnotetext{
${ }^{87}$ Maimon Mohatar Boaza. CDMH, SE Masonería A, L. 32 E. 2-A.

${ }^{88}$ Maimon Mohatar Boaza. CDMH, SE Masonería A, L. 32 E. 2-A.

${ }^{89}$ Informe de Tomás de Lora para Oriente no. 451, 25 de abril de 1933, sobre Trahami Ben Abdel-Lah, El Uazani. CDMH, SE Masonería, A L. 32 E. 16.

${ }^{90}$ Informe de Hossain Ben Mohamed Hehe para Oriente no. 451, 25 de marzo de 1933.

${ }^{91}$ Citado en Zapata Barrero, "La reproducción del "otro" musulmán en España a través de prácticas sociales y reacciones políticas", en El otro en la España Contemporánea, Prácticas, discursos y representaciones, coords. Silvina Schamma Gesser y Raanan Rein (Sevilla: Fundación Tres Culturas, 2011), 222.
} 
público $^{92}$ y no tanto el islam en sí. Moga Romero ${ }^{93}$, en ese sentido, ha apuntado que "no se trata de una trayectoria en el imaginario y la construcción del otro que viene desde la Edad Media, dada la cercanía y la labor de puente de ambos países, sino de una fractura cultural entre moros y cristianos, una falla histórica, como preconizan los valedores de un choque de civilizaciones entre Oriente y Occidente. En general, un conflicto entre modelos de sociedad (una occidental y la otra musulmana) que son incompatibles.

Por otra parte, las ideas políticas relativas al nacionalismo marroquí, tampoco supusieron, en primera instancia, una exclusión directa a la hora de valorar el ingreso en las logias, al menos no desde que se afianzó su bagaje a principios de los años 30 . Es más, como confirman los expedientes personales, la mayoría de los masones musulmanes, o pertenecían a dicho movimiento o bien se mostraban simpatizantes y acordes a su ideología, como vemos a propósito del informe de solicitud de Abdeljalaq Torres, en el que se advertía su condición de "patriota nacionalista" pero que también era "amante de la libertad, es decir, que aboga por que se respete a cada nación sus usos y costumbres tradicionales"94. Es significativo en este sentido, cómo el autor de esta evaluación, Abdeselam Bennuna, y el evaluado, Torres, fueron "perfectos" masones a la vez que dos de los principales representantes del nacionalismo musulmán, entendido este, en los albores de 1931, tanto por los masones protectores como por los protegidos, como

el deseo de muchos musulmanes de instruirnos en lo moderno, sin abandonar lo que es peculiar nuestro. Comprendemos que, con relación a Europa, estamos atrasados de un siglo, y es nuestro más ferviente deseo el de ver si esta laguna podemos salvarla en el menor plazo de tiempo posible. Como la misión que aquí se ha impuesto España, no es otra, venimos a sacar en consecuencia que el primer nacionalista $^{95}$ de la Zona es el propio país protector ${ }^{96}$.

Los representantes del movimiento nacionalista, en su inicio, no cuestionaban el protectorado, al contrario, aceptaban el rol paternalista que la metrópoli y la masonería les concedía con el objeto de lograr sus fines. Como sujetos colonizados involuntariamente, pero siendo conscientes de las deficiencias de su administración, educación, sanidad y

\footnotetext{
92 Zapata Barrero, "La reproducción del "otro" musulmán en España a través de prácticas sociales y reacciones política", en El Orientalismo desde el sur, coord. José Antonio González Alcantud et al. (Barcelona: Consejería de Cultura de la Junta de Andalucía, Anthropos Editorial, 2006), 253.

${ }^{93}$ Vicente Moga Romero, "El imaginario de papel, el papel del imaginario: un trampantojo oriental", en El Orientalismo desde el sur, coord. José Antonio González Alcantud et al (Barcelona: Consejería de Cultura de la Junta de Andalucía, Anthropos Editorial, 2006), 97-146.

${ }^{94}$ En un informe de Abdeselam Bennuna de 4 de julio de 1932 sobre Abdeljalaq Torres. CDMH, SE Masonería A, L. 95 E. 7.

${ }^{95}$ [Subrayado en el original].

96 Trabajo de A. Bennuna sobre el nacionalismo musulmán y el panislamismo. CDMH, SE Masonería A, L.351 E. 21.
} 
justicia, comprendían que la lucha debía realizarse desde dentro, promoviendo desde las logias la introducción de una serie de mejoras en estos ámbitos ${ }^{97}$ y no por medio de disputas "revolucionarias" en las que siempre estarían en desventaja militar, tecnológica y geopolíticamente. Rocío de Velasco ${ }^{98}$, establece ciertas similitudes entre el nacionalismo marroquí y la masonería que podría ayudar a clarificar la vinculación entre ambos. En primer lugar, el nacionalismo sentaba sus bases en la modernización de las instituciones y estructuras autóctonas, pero conservando su esencia islámica, y los preceptos promulgados por la orden con cierta base religiosa a pesar de su modernidad, cuajaban sin contradicción. Además, el nacionalismo marroquí en nada se relacionaba al de tipo fascista alemán o italiano que tanto denunciaban las logias, ni tampoco al franquista posterior. Es más, los partidarios del movimiento, como sujetos colonizados, se mostraban contrarios a la preeminencia de un pueblo sobre otro en función de su mayor o menor grado de desarrollo o civilización ${ }^{99}$, hecho que les acercaba no solo a los ideales liberales masónicos sino a los propios republicanos. Aunque esta premisa entraba en contradicción directa con el canon colonial.

En segundo lugar, buena parte de los valores defendidos por la masonería eran comunes al islam y a su solidaridad comunitaria en torno a la Umma, o comunidad de creyentes, al igual que sus principios fundamentales y valores universales en torno al bien y la justicia que formaban parte del credo de ambos. Y, por último, arguye la autora que la masonería brindaba a los nacionalistas la oportunidad de entrar en contacto con importantes personalidades de la vida política y social españolas. Solo así podrían demandar y reclamar aquellas situaciones o elementos que consideraban injustos en función de sus postulados anticolonialistas, pues no podían establecerse por medio de partidos políticos cuya inexistencia era sugerente en el protectorado, sobre todo durante la época republicana, ni tampoco habían tenido respuesta a través de los cauces oficiales.

Lo cierto es que la introducción de este debate en seno de las logias, formaba parte de esta última estrategia, en la que los nacionalistas intentaron discurrir y buscar los apoyos necesarios que desde las autoridades civiles se les negaba, amparándose precisamente en los ideales de libertad, igualdad y fraternidad que en ellas se defendía. La única salvedad fue que también "los permisivos masones españoles" hacia su discurso, pretendían hacer uso de la causa que reivindicaban para sus propios logros. Es decir, pretendían encauzar el movimiento en beneficio de la patria española y su acción en el protectorado, además de

\footnotetext{
${ }^{97}$ Uno de los centros influyentes en este sentido, fue el Ateneo, que se convirtió en un instrumento de la colonización. Irene González González, "Escuela e ideología en el protectorado español en el norte de Marruecos (1921-1956)" (Tesis de doctorado en historia, Universidad de Castilla la Mancha, 2010), $257-258$.

${ }^{98}$ Rocío de Velasco Castro, "La represión contra la población civil del protectorado español en Marruecos", Hispania Nova. Revista de Historia Contemporánea $10 \quad$ (2012): 1-17, http://hispanianova.rediris.es/10/dossier/10d006.pdf

${ }^{99}$ De Velasco Castro, "La represión contra la población civil”, 6-7.
} 
conseguir, gracias a esta propaganda complaciente y tolerante, la iniciación de nuevos miembros musulmanes que a su vez adoptaran los preceptos masónicos.

La discusión llevada a cabo en la tenida de Luz no. $449^{100}$, el 5 de julio de 1932 al respecto de la iniciación del líder del movimiento, A. Torres, es un ejemplo de la fricción que el nacionalismo marroquí producía respecto a la cohesión del grupo y los fines de la institución. El venerable del taller, abría el debate confirmando que era "perjudicial el ingreso en la orden de indígenas que se distingan en estas ideas por los contratiempos internacionales que ello puede ocasionar a España en su cometido de Protectorado de Marruecos", a lo que otro componente añadía, "tratándose de musulmanes cultos con ideas nacionalistas y puesto que indudablemente uno de los más grandes ideales de la orden es el de apoyar todo cuanto signifique la libertad e independencia absoluta de los pueblos, teniendo a estos profanos en el seno de la orden, pueden ser controlados y guiados estos ideales para su más feliz realización". Al final, coinciden en que "se debe proceder con mucho cuidado, procurando distinguir entre el nacionalismo y el panislamismo, creyendo que el profano Torres profesa el primero de estos ideales por lo que considera que los informes de este taller, no pueden ser desfavorables sin que por ello dejen de hacerse las correspondientes observaciones".

Irremisiblemente, los talleres del protectorado no tardarían en posicionarse en contra del movimiento, no tanto por la relevancia social que había ido adquiriendo durante los años 30, sino porque, desde las autoridades civiles españolas y francesas, se estaba interrelacionando a la masonería con el nacionalismo marroquí. En 1933, las voces de algunos talleres españoles se impusieron de un modo desfavorable:

Huelga decir que me refiero al nacionalismo de Marruecos, y en particular por lo que respecta al h. Bennuna, cabeza visible de este movimiento político que es necesario estudiar con el mayor detenimiento por la gravedad que encierra, tanto para la Francmasonería como para nuestra amada España; y hasta quizás también, para el tesoro inapreciable de la República democrática que, tras continuos y penosos esfuerzos de un puñado de hombres honrados y valerosos, hemos logrado ver instaurada ${ }^{101}$.

El dilema llegaría a su fin con el decreto de la Gran Logia de Marruecos de $1933^{102}$ por el que se declaraba incompatible la masonería con el nacionalismo. El resultado fue arrollador, pues a partir de julio de ese año los masones pertenecientes al movimiento nacionalista marroquí no volvieron a asistir a las tenidas, ni entregaron por escrito su

\footnotetext{
${ }^{100}$ Acta de Atlántida no. 448 de 5 de julio de 1932. CDMH, SE Masonería A, L. 404 E. 2.

${ }^{101}$ Trabajo de Aurelio Clemente leído el 5 de mayo de 1933 en Atlántida no. 448. CDMH, SE Masonería, A L. 148 E. 9.

${ }^{102}$ Acta de 4 de julio de 1933 de la Gran Logia de Marruecos. CDMH, SE Masonería A L. 499.
} 
elección del decreto (la decisión de elegir entre ser masón o ser nacionalista). Y si bien algunos solicitaron su plancha de quite, su continua ausencia a las reuniones supuso que fueran irradiados a lo largo del año. Por otro lado, la causa de estas deserciones podría haber estado relacionada con las terribles persecuciones que también sufrieron los musulmanes a causa de su condición de masones y que, de modo alarmante, se indica en el informe enviado al Soberano Consejo de Gobierno de la Gran Logia Española el 4 de octubre de $1934^{103}$.

No obstante, el punto de inflexión entre la masonería y el nacionalismo marroquí, vendría determinado desde el mismo instante en que su lucha colisionaba con los intereses de la orden, relacionados directamente con su destino histórico como institución y la identidad de su propia nación. Es decir, aceptar el nacionalismo marroquí de los componentes de las logias implicaba, necesariamente, renunciar a la consecución de su ideal, pero, sobre todo, afectaba a sus pretensiones universalistas y cosmopolitizadoras que definían a la orden como la institución perfecta cuasi-divina, para regenerar y mejorar su país y, por extensión, el territorio bajo su protección. Era tanto renunciar a la patria como a su imaginario masónico de proyección magrebí. Desde este punto de vista, la misión de la orden no se había concluido. Al igual que en Cuba y Filipinas, los nacionalistas podrían haber considerado que la masonería actuaría en favor de su causa. Pero Marruecos no era Cuba, ni tampoco Filipinas. ${ }^{104}$ Era, al contrario, el territorio de los infieles, el territorio de los moros salvajes, exóticos y bárbaros desde la representación más castiza de su imaginario cultural. En este sentido, en el protectorado no podía sino primar el deber de civilizar tal incivilización, primar la patria española, la República, y el papel protagonista de la orden, por encima de cualquier reivindicación colonial.

A pesar de ello, esta crisis existencialista no fue homogénea para todo el territorio magrebí. Los talleres españoles auspiciados por la Gran Logia Española, a diferencia de los adscritos a la Gran Logia de Marruecos, no presentaron la misma fricción acaecida en 1933. Es más, en sus filas no dejaron de iniciarse musulmanes y, aunque su número sigue siendo bajo, fueron las logias que más musulmanes conocieron en sus listas, especialmente, Perseverancia no. 70 de Larache $^{105}$. La causa de ello se debe a que algunos de los componentes de estos talleres, a veces a título individual y otras por medio de la orden, colaboraron, propiciaron y protegieron a muchos integrantes del movimiento nacionalista marroquí del conjunto del protectorado, fuesen masones o no. De hecho, su colaboración continua se tradujo en una pugna incesante - tal y como se comprueba en la numerosa correspondencia que disponemos - en pro de la emancipación del pueblo marroquí y

\footnotetext{
${ }^{103}$ Larache, 16 de marzo de 1933, firmado por B. Pajares de Perseverancia no. 70. CDMH, SE Masonería A, L. 420 E. 1.

104 De Paz, "España, Cuba y Marruecos", 273-310.

${ }^{105}$ A partir de los cuadros lógicos de la logia se calculan un total de 6 musulmanes entre 1930 y 1936 , años correspondientes a la existencia del taller. CDMH, SE Masonería A, L. 390 y 391.
} 
contraria, por ende, al colonialismo europeo. Destacaron en ello Jaime y Marcelo de Argila $^{106}$, miembros de la logia Delta no. 12 de Barcelona y la logia larachense antes mencionada. En este sentido, algunos masones y nacionalistas, en connivencia, participaron como corresponsales ante la Sociedad de Naciones en Ginebra, el Comité Panislámico y otras asociaciones similares. $\mathrm{Y}$ en otros momentos, incluso, se elevaron diferentes comunicados a las altas instancias masónicas y civiles para favorecer la puesta en libertad de algunos nacionalistas que habían sido encarcelados en la zona francesa ${ }^{107}$. Por último, como curiosidad significativa, algunos masones norteafricanos propusieron a Jaime de Argila, el máximo representante de esta corriente pro-nacionalista de la colonia, como alto comisario del protectorado español, el puesto más alto de la administración española ${ }^{108}$. No obstante, como puede deducirse, esto produciría cierta dicotomía en el seno de las logias, pues a pesar de que la elección hubiese supuesto cierta hegemonía e influencia política de la orden en la gestión política del protectorado, además, a su vez, de interrumpir con ello las persecuciones que sufrían desde 1931, también simbolizaba una mayor hegemonía e influencia de los nacionalistas en este mismo aspecto.

De todos modos, es indudable de que la interrelación entre masones y nacionalistas

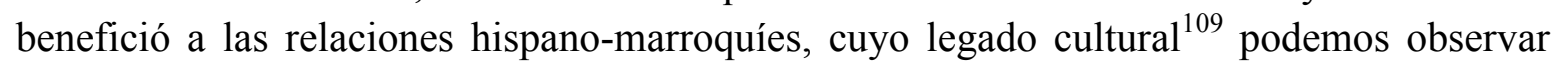
hoy en los fondos masónicos del Centro Documental de la Memoria Histórica. Legado que, además, hemos estado analizando a lo largo de estas páginas. No hay más que comprobar la variedad de homenajes que la población marroquí dedicó al señor Argila con motivo su muerte en 1934. Las palabras producidas por A. Bennuna al hijo de este, Marcelo de Argila, no dejan ninguna duda sobre su "obra imperecedera",

Prueba de ello es que al conocerse la noticia en esta región, inmediatamente le dirigimos un telegrama firmado por los más destacados del mundo expresándole nuestro testimonio de sincero pesar por la pérdida sufrida por uds los familiares y por nosotros, del gran defensor de la Justicia del pueblo Musulmán. Duelo solemne guardará el pueblo musulmán por la pérdida del prohombre y preclaro varón que

\footnotetext{
${ }^{106}$ Expedientes masónicos: CDMH, SE Masonería A, L. 203, E. 1. y L. 55 E. 15.

${ }^{107}$ Carta al Soberano Consejo de Gobierno de la Gran Logia Española de 19 de julio de 1934 informando de la detención de dos masones musulmanes de la logia y de otros 5 no pertenecientes a la orden, acusados de nacionalismo. CDMH, SE Masonería A, L. 95 E. 11.

${ }^{108}$ Esto se puede observar en diferentes cartas de Atlántida no. 448 de Tetuán, entre abril y septiembre de 1932 a Jaime de Argila. CDMH, SE Masonería A, L. 16 E. 8.

${ }^{109}$ Véase Aguiar Bobet, "Revistas, folletos y publicaciones masónicas del Norte de África: otra cara del legado cultural de las relaciones hispano-marroquíes", en La historia, Lost in traslation?, eds. Damían González, Manuel Ortiz y Juan S. Pérez, (Albacete: Universidad de Castilla la Mancha, 2017), 2563-2575, http://seft.uclm.es/noticias/2017/03/30/actas-del-xiii-congreso-de-la-asociacion-de-historia-contemporanea$\underline{\mathrm{uclm} /}$
} 
supo en vida captarse las simpatías de todo un pueblo por la humanitaria labor que en defensa de sus derechos ha realizado haciendo prevalecer la Justicia ${ }^{110}$.

\section{La utopía está en el horizonte: ser o no ser masón}

Antes de concluir, no podemos olvidar que las nociones sobre la identidad y la alteridad son siempre recíprocas y bilaterales, lo que nos lleva a replantearnos y reconsiderar cómo a pesar de las contradicciones discursivas que hemos ido destacando, ciertos musulmanes fuesen nacionalistas o no, asumieron su condición masónica en los talleres españoles. Es decir, se definieron como tales. Lo que nos lleva, a su vez, a sugerir el proceso contrario, aquellos condicionantes que impidieron que la gran mayoría de los marroquíes no quisieran o no pudieran identificarse en estos términos. En este sentido, no podemos obviar que el escaso número de integrantes musulmanes en las logias — que más bien indicaba el escaso resultado de la cultura de la tolerancia-, se debía a la representación del otro musulmán de sobra mencionada en este trabajo, pero, también, se debió al ejercicio de una política errónea. El problema derivaba del propio constructo. Es decir, el discurso ofrecido nunca fue comprendido ni asumido en su totalidad por la generalidad indígena, del mismo modo que siempre fue interpretado a conveniencia de los intereses concretos de aquellos que sí se iniciaron en la orden. Y tal vez, uno de los aspectos claves que podrían explicar esta incomprensión fue el desconocimiento generalizado de la lengua española por los protegidos y, viceversa, el desinterés hacia la lengua árabe por los españoles, tal y como advertíamos en nuestro anterior trabajo ${ }^{111}$. El único vehículo de las ideas, el instrumento más útil para inculcar un determinado discurso, no fue escatimado ni potenciado por ninguno de los dos frentes: ni las autoridades civiles, ni la masonería. Es más, poquitísimos masones españoles conocían sus fundamentos, ${ }^{112}$ por lo que muchas veces carecían de intérpretes para las reuniones, del mismo modo que, aunque se planteara en los reglamentos, nunca se tradujeron estos ni otras obras esenciales del ritual, ni tampoco simples folletos con la finalidad de propagar sus preceptos ${ }^{113}$. Además, la ignorancia y la torpeza hacia la heterogeneidad de tradiciones culturales, étnicas y religiosas del Imperio marroquí por parte de los españoles, impidieron que el discurso masónico y su proyección fueran inteligibles, especialmente si consideramos el conflicto entre ambas culturas. Es decir, la falla cultural existente tanto por la representación de la

\footnotetext{
${ }^{110}$ Carta de A. Bennuna a Marcelo de Argila, 8 de octubre de 1934. CDMH, SE Masonería A, L. 95 E. 15.

111 Aguiar Bobet, "La cultura de la tolerancia".

${ }^{112}$ Eran intérpretes de árabe dos españoles, un judío y cinco musulmanes, lo que confirma un esfuerzo mayor de integración por parte del colonizado que del colonizador.

${ }^{113}$ Rocío de Velasco menciona que el reglamento de Atlántida no. 448 fue traducido por el masón Tuhami alWazzani, a partir del diario de Abdeljalaq Torres (23-12-1933) traducido por Ibn 'Azzūz Hakīm en 1992. De Velasco, "La represión contra la población civil", 10. Pero no consta esta información en la documentación consultada en los fondos del CDMH, ni el inicio de este individuo ni dicha traducción.
} 
religión en el espacio público como por la noción evolucionista de la modernidad masónica en la que todas las pretensiones de los sujetos colonizados quedaban reducidas a la barbarie y sometidas a un paternalismo justificado.

Partiendo de esta incomprensión, de estas fricciones discursivas ¿qué elementos llevaron entonces a la intención de algunos musulmanes de identificarse con la masonería y adentrarse en sus preceptos? A lo largo del artículo ya hemos ido dilucidando algunas de las variables que pudieron producir la asunción de la condición masónica por parte de este grupo. Por ejemplo, la sociabilidad masónica representaba para los nacionalistas marroquíes un vehículo político por el que reivindicar sus demandas, especialmente con la ausencia y prohibición de los partidos políticos en el protectorado y con la escasa atención que este régimen les condecía. Las logias representaban, en este caso, el papel que la ausencia e indiferencia de ambas variables producía. De este modo, la autorización de la primera asociación del movimiento ${ }^{114}$, motivada a su vez por el decreto de las logias de 1933 que condenaba su incompatibilidad con la masonería, derivaría en la "fuga masiva" de los musulmanes de los talleres españoles. El papel de la masonería, desde ese momento, ya no era imprescindible.

Junto a ello, las formas de la sociabilidad masónica no entraban en contradicción con la cultura religiosa marroquí ni con las bases de su comunidad, la Umma. Esto significó que parte del ritual, de las formas de interactuación en los talleres y de los preceptos de la orden (perfeccionamiento del hombre, de la humanidad, igualdad religiosa, universalismo, beneficencia, etcétera), no colisionaran con su condición de musulmanes, especialmente, con su credo islámico. A diferencia de lo que ocurriría con las organizaciones teosóficas que se expandieron por el protectorado durante este mismo cómputo temporal, la masonería, como "religión laica ${ }^{115 "}$ no cuestionó los postulados islámicos ni mucho menos pretendió ofrecer la visión heterodoxa de este que sí plantearía la Sociedad Teosófica y la Orden de la Estrella de Oriente ${ }^{116}$.

Por último y, quizás, más significativo en esta producción y reconstrucción de identidades, fue, simplemente, la comprensión y, más que eso, la aceptación de algunos musulmanes masones, del ideal masónico promulgado por las logias norteafricanas. Con ello nos referimos, no solo a la afirmación de los nacionalistas marroquíes de que su pueblo y su nación estaban "atrasadas más de un siglo" y por ello necesitaban la protección española como vía para alcanzar la civilización, tal y como vimos en los trabajos de A.

\footnotetext{
${ }^{114}$ De Velasco, "La represión contra la población civil", 7.

${ }^{115}$ Bryon-Portet, Sociologie de socieétés fermés, 50.

116 Aguiar Bobet, "Soldados orientalistas: teosofía y masonería en el Magreb durante la II República Española", REHMLAC+ 8, no. 2 (diciembre 2016-abril 2017): 95-117, https://doi.org/10.15517/rehmlac.v8i2.26648. Aguiar Bobet, "La seducción del esoterismo; masones y teósofos en el Protectorado español de Marruecos", Melancolía 2 (2017): 78-103, http://www.revistamelancolia.com/index.php/melancolia/article/view/19/23
} 
Bennuna para su taller; sino, más bien, al hecho de que estos individuos reconocieron a la institución masónica como el organismo que mejor podía conducirles al estadio que deseaban alcanzar. Es decir, que se lograse construir en Marruecos, más que una nación civilizada, un verdadero paraíso utópico, un crisol de base masónica e islámica, conciliadora con la multiculturalidad. Y esto significaba, por extensión, aceptar el destino histórico y cuasi divino de la masonería, inherente en su imaginario sociocultural, tal y como lo asumían los propios masones españoles. Así lo ilustraría el masón Ben Mohamed Zuak:

Antes de mi ingreso (...) oía hablar de las buenas intenciones de la Masonería y su noble lema, sus esfuerzos para la felicidad de la Humanidad, su vela sobre la tranquilidad y el porvenir vago de la gente. Oía hablar de sus nobles principios y de su único fin que no es otra cosa que el trabajo y el sacrificio, en todo lo posible, constantemente y siempre en pro de la Paz y contra la Guerra. Para la libertad, la igualdad y la fraternidad. (...). Cuando las circunstancias me han favorecido y tuve el honor y la suerte de ingresar en la Masonería y encontrarme masón (gracias a ustedes q.: h.:) me he convencido de la realidad de lo que oía (...)Estoy seguro de que la fraternidad masónica es una realidad inmaculada e intachable muy lejos de los intereses personales y de la mira política y que su organización no puede nunca ser alterada y que el hermano masón está siempre dispuesto para sacrificarse y para sacrificar todo lo que posee para defender a sus hermanos y a la masonería, como para salvar a sus semejantes de los peligros de la ignorancia, la esclavitud y la injusticia, porque los derechos del hombre son sagrados para la persona de buen juicio y alma noble ${ }^{117}$.

Sin embargo, estas disquisiciones no podrían sostenerse sin tener en cuenta que los musulmanes iniciados en las logias ya habían empezado el camino de la "civilización". Muchos de ellos habían estudiado en El Cairo o en París y habían adoptado muchos de los preceptos cosmopolitas y de la modernidad europea, incluida cierta secularización, que incentivaba, quizás sin pretenderlo, una aproximación mayor a los ideales que promulgaba la Orden. Y, en este sentido, podían identificarse con ella fácilmente. Y más que eso, en la masonería, se encontraban entre "iguales".

En definitiva, debemos matizar que, en este juego de construcciones y reconstrucciones discursivas de identidades masónicas y no masónicas, tan complejo como heterogéneo, la producción de identidades por parte de la masonería no iría mucho más allá de las de otros agentes civilizatorios. No obstante, y contra todo pronóstico, su actuación cosmopolitizadora y tolerante marcaría una distinción importante. Una singularidad en la que, lejos de incluir exclusivamente la condición de civilizar y adiestrar en los preceptos de

${ }^{117}$ Trabajo leído el 4 de junio de 1934. CDMH, SE Masonería A, L. 33 E. 8. 
la orden a través de la asimilación, fomentaría la convicción de algunos marroquíes, al menos a priori, de que podía ser posible una verdadera e igualitaria inclusión de la diferencia, y una verdadera conciliación intercultural. El ideal masónico, aunque sin su condición colonial, quedaría implantado, al menos, en las percepciones de los sujetos colonizados que se iniciaron en sus misterios. Y tal vez, prueba de ello sería que, en Marruecos, se constituyeron nuevas logias masónicas musulmanas después de su independencia $y$, en la zona francesa, algunas continuaron sus trabajos ${ }^{118}$. En otras palabras: el problema nunca provino de los preceptos masónicos, ni de la condición identitaria de ser masón, por muy europeos y cosmopolitas que fueran sus principios. El problema fue, más bien, colonial y patriótico. Es decir, el "error" de la masonería española fue, precisamente, su discurso colonial, en la que España y la patria española nunca serían puestas en entredicho. Primero eran españoles y, después, masones. Y lo mismo, por supuesto, sucedía al respecto de los marroquíes y su nación.

Quizás, lo más esclarecedor de todo esto es la capacidad camaleónica de la masonería respecto a la heterogeneidad de los individuos que se inician en ella y los contextos diversos en los que participa, tanto geográficos como temporales. No obstante, los principios idealistas y utópicos en su papel nacional e internacional, provenientes de su cosmopolitismo y universalismo, parecen ser su común denominador. Citando el último enunciado de uno de los poemas más conocidos de Eduardo Galeano, "¿para qué sirve la utopía? Para esto sirve, para caminar”.

\section{Bibliografía}

Aixelá Cabré, Yolanda et al. Tras las huellas del colonialismo español en Marruecos y en Guinea Ecuatorial. Madrid: CSIC, 2015.

Aguiar Bobet, Valeria. "Soldados orientalistas: teosofía y masonería en el Magreb durante la II República Española”. REHMLAC+ 8, no. 2 (diciembre 2016-abril 2017): 95117. https://doi.org/10.15517/rehmlac.v8i2.26648

Aguiar Bobet, Valeria. "En busca de la colonia perfecta: ideales masónicos en Cuba y Marruecos”. Ponencia presentada en V Simposio Internacional de la Masonería Latinoamericana y Caribeña. La Habana, 26-30 de junio de 2017.

Aguiar Bobet, Valeria. "La seducción del esoterismo; masones y teósofos en el Protectorado español de Marruecos”. Melancolía 2 (2017): 78-103. http://www.revistamelancolia.com/index.php/melancolia/article/view/19/23

Aguiar Bobet, Valeria. "La cultura de la tolerancia en el Marruecos de la II República: el VIII Centenario de Maimónides”. En La masonería hispano-lusa y americana, De

\footnotetext{
${ }^{118}$ Georges Odo, La Franc-maçonnerie en Afrique, 121.
} 
los Absolutismos a las Democracias (1815-2015). Coordinado por José Miguel Delgado e Yván Pozuelo. Zaragoza: CEHME, 2017.

Aguiar Bobet, Valeria. "La masonería española en el protectorado marroquí: la construcción de un proyecto cosmopolitizador". En 300 años: masones y masonería 1717-2017. Tomo V: Cosmopolitismos. Editado por Ricardo Martínez Esquivel, Yván Pozuelo y Rogelio Aragón. Ciudad de México: Palabra de Clío, 2017.

Arias Andrés, Felipe y Felipe, Helena de. Imágenes coloniales de Marruecos en España. Madrid: Mélanges de la Casa de Velázquez, 2007.

Aziza, Mimoun. "La sociedad marroquí bajo el Protectorado español (1912-1956)". En El Protectorado español en Marruecos: la historia trascendida, Vertiente jurídica, socioeconómico-demográfica y científico-educativa. Dirigido por Manuel Aragón Reyes. Bilbao: Iberdrola, 2013.

Beaurepaire, Pierre-Yves. "Perception et réception des musulmans dans les loges maçonniques du siècle des Lumières". Cahiers de l'Orient, (2016).

Beaurepaire, Pierre-Yves. La république universelle des francs-maçons. De Newton à Metternich. Rennes: Ouest-France, 1999.

Bryon-Portet, Céline. Sociologie de sociétés fermés. Imaginaire symbolique et sacralité en miieu clos. Montpellier: Presses universitaires de la Méditerranée, 2013.

Carretero Pasín, A. Enrique. "Imaginario y sociedad. Un acercamiento a la sociología de lo imaginario en la tradición francesa". Revista Internacional de Sociología 41 (mayoagosto, 2005): 137-161.

Dürand, Gilbert. Las estructuras antropológicas de lo imaginario. Madrid: Taurus, 1982.

González Alcantud, José Antonio et al. El Orientalismo desde el sur. Barcelona: Consejería de Cultura de la Junta de Andalucía, Anthropos Editorial, 2006.

González González, Irene. "Escuela e ideología en el protectorado español en el norte de Marruecos (1921-1956)". Tesis de Doctorado en Historia, Universidad de Castilla la Mancha, 2010.

Jaramillo Marín, Jefferson. “Cosmopolitismo(s) y modernidade(s)”. Diálogo de saberes 29 (julio-diciembre 2008): 175-200.

Jover, José María. "La percepción española de los conflictos europeos: notas históricas para su entendimiento". Revista de Occidente 57 (1986): 13-42.

López, Bernabé. "Los españoles en Tánger". AWRAQ: Estudios sobre el mundo árabe e islámico contemporáneo 5-6 (2012): 1-46.

Madariaga, $\mathrm{M}^{\mathrm{o}}$ Rosa de. Los moros que tajo Franco. Madrid: Alianza, 2015.

Mateo Dieste, Josep Lluis. "Una hermandad en tensión. Ideología colonial, barreras e intersecciones hispano-marroquíes en el Protectorado". AWRAQ: Estudios sobre el mundo árabe e islámico contemporáneo 5-6 (2012): 79-96. 
Martín Corrales, Eloy. "Maurofobia/islamofobia y maurofilia/islamofilia en la España del siglo XXI". CIDOB de Afers Internacionals 66-67(2004): 39-45.

Martín Corrales, Eloy. La imagen del magrebi en España. Una perspectiva histórica siglos XVI-XX. Barcelona: Bellaterra, 2002.

Martín Corrales, Eloy. Marruecos y el colonialismo español (1859-1912). De la guerra de África a la "penetración pacifica”. Barcelona: Bellaterra, 2002.

Martín-Márquez, Susan. Desorientaciones. El colonialismo español en África y la performance de la identidad. Barcelona: Ediciones Bellaterra, 2011.

Moga Romero, Vicente. Al oriente de áfrica. Masonería, Guerra Civil y represión en Melilla (1894-1936). Melilla: UNED-Centro Asociado de Melilla, 2005.

Mudimbe, Valentin-Yves. The invention of Africa. Indianápolis: Indiana University Press, 1998.

Nerín, Gustau. La última selva de España. Antropófagos, misioneros y guardias civiles. Madrid: Catarata, 2010.

Odo, Georges. La franc-maçonnerie en Afrique francophone, 1781-2000. París: Éditions Maçonniques de France, 2000.

Odo, Georges. La franc-maçonnerie dans les colonies, 1738-1960. París: Éditions Maçonniques de France, 2001.

Páez-Camino Arias, Feliciano. "El Magreb en las relaciones hispano-francesas". Stud. His., $H^{a}$. contemporánea 13-14 (1995): 199-213.

Paz Sánchez, Manuel de. "España, Cuba y Marruecos: masonería, identidades y construcción nacional". Anuario de Estudio Atlánticos 55 (2009): 273-310.

Pizarro, Ana. "Colonialidad: observaciones sobre la construcción de discursos". Taller de Letras 53 (2013): 83-97.

Said, Edward. Orientalismo. Traducido por María Luisa Fuentes. Madrid: Quilba,1990.

Sánchez Molina, Raúl. "Homo infantilis: asimilación y segregación en a política colonial española en Guinea Ecuatorial”. Revista de Dialectología y Tradiciones Populares 57, no. 2 (2002): 105-120.

Sampedro Vizcaya, Benita. "Rethinking the Archive and de Colonial Livrary: Equatorial Guinea". Journal of the Spanish Cultural Studies 9, no. 3 (2008): 342.

Schammah Gesser y Silvina; Rein, Raanan. El otro en la España Contemporánea. Prácticas, discursos y representaciones. Sevilla: Fundación Tres Culturas del Mediterráneo, 2011.

Stallaert, Christiane. Etnogénesis y etnicidad en España. Barcelona: Proyecto A. Ed., 1995.

Velasco Castro, Rocío de. "La represión contra la población civil del protectorado español en Marruecos". Hispania Nova. Revista de Historia Contemporánea 10 (2012): 117. http://hispanianova.rediris.es/10/dossier/10d006.pdf 
Zukier, Henri. "Transformation of Hatred: Anti-Semitism as Struggles for Group Identity". En Demonizing the Other: Antisemitism, Racism and Xenophobia. Coordinado por Robert S. Wistrich. Londres: Routledge, 2003. 